Article

\title{
Bioactive Molecules Release and Cellular Responses of Alginate-Tricalcium Phosphate Particles Hybrid Gel
}

\author{
Dipankar Das ${ }^{1,2} \mathbb{C}^{D}$, Sumi Bang ${ }^{1}$, Shengmin Zhang ${ }^{3}$ and Insup Noh ${ }^{1,2, *}$ \\ 1 Convergence Institute of Biomedical Engineering and Biomaterials, Seoul National University of Science of \\ Technology, 232 Gongneung-ro, Nowon-gu, Seoul 01811, Korea; dipankardas@seoultech.ac.kr (D.D.); \\ bobosumi48@gmail.com (S.B.) \\ 2 Department of Chemical and Biomolecular Engineering, Seoul National University of Science of Technology, \\ 232 Gongneung-ro, Nowon-gu, Seoul 01811, Korea \\ 3 Advanced Biomaterials and Tissue Engineering Center, Huazhong University of Science and Technology, \\ Wuhan 430074, China; smzhang@mail.hust.edu.cn \\ * Correspondence: insup@seoultech.ac.kr; Tel.: +822-970-6603; Fax: +822-977-8317
}

Received: 7 October 2017; Accepted: 13 November 2017; Published: 14 November 2017

\begin{abstract}
In this article, a hybrid gel has been developed using sodium alginate (Alg) and $\alpha$-tricalcium phosphate $(\alpha-\mathrm{TCP})$ particles through ionic crosslinking process for the application in bone tissue engineering. The effects of $\mathrm{pH}$ and composition of the gel on osteoblast cells (MC3T3) response and bioactive molecules release have been evaluated. At first, a slurry of Alg and $\alpha$-TCP has been prepared using an ultrasonicator for the homogeneous distribution of $\alpha$-TCP particles in the Alg network and to achieve adequate interfacial interaction between them. After that, $\mathrm{CaCl} 2$ solution has been added to the slurry so that ionic crosslinked gel (Alg- $\alpha-\mathrm{TCP})$ is formed. The developed hybrid gel has been physico-chemically characterized using Fourier transform infrared (FTIR) spectroscopy, scanning electron microscopy (SEM) and a swelling study. The SEM analysis depicted the presence of $\alpha$-TCP micro-particles on the surface of the hybrid gel, while cross-section images signified that the $\alpha$-TCP particles are fully embedded in the porous gel network. Different $\%$ swelling ratio at $\mathrm{pH} 4,7$ and 7.4 confirmed the $\mathrm{pH}$ responsiveness of the Alg- $\alpha$-TCP gel. The hybrid gel having lower $\% \alpha$-TCP particles showed higher \% swelling at $\mathrm{pH}$ 7.4. The hybrid gel demonstrated a faster release rate of bovine serum albumin (BSA), tetracycline (TCN) and dimethyloxalylglycine (DMOG) at $\mathrm{pH} 7.4$ and for the grade having lower $\% \alpha$-TCP particles. The MC3T3 cells are viable inside the hybrid gel, while the rate of cell proliferation is higher at $\mathrm{pH} 7.4$ compared to $\mathrm{pH}$ 7. The in vitro cytotoxicity analysis using thiazolyl blue tetrazolium bromide (MTT), bromodeoxyuridine (BrdU) and neutral red assays ascertained that the hybrid gel is non-toxic for MC3T3 cells. The experimental results implied that the non-toxic and biocompatible Alg- $\alpha$-TCP hybrid gel could be used as scaffold in bone tissue engineering.
\end{abstract}

Keywords: alginate; $\alpha$-TCP particles; drug delivery; hybrid gel; MC3T3 cell responses

\section{Introduction}

Hydrogels are hydrophilic, three-dimensional (3-D), physically or chemically crosslinked polymer networks which absorb large amount of water in aqueous medium or biological fluids $[1,2]$. The excellent swelling nature of the hydrogel helps to retain water molecules into the 3-D network that aids in keeping biocompatibility, structural integrity and elasticity [1]. Owing to these features, hydrogels have been extensively employed in different biomedical applications such as drug delivery [1-3], protein delivery [3], tissue engineering [4-7] and regenerative medicine [7]. Researchers have also 
explored that the incorporation of micro/nano-sized fillers into polymeric hydrogels forms composite hydrogels with improved mechanical properties, unique rheological behaviors, promising degradation features and enriched bioactivities [8-10]. However, the direct incorporation of inorganic fillers leads to unstable mixtures of the polymeric and inorganic phases [10]. This causes isolation of the inorganic particles from the hydrogel network over a prolonged period of time, or during the swelling-deswelling process, because of the absence of strong interactions between the inorganic particles and the polymer matrix [10]. Recently, hybrid hydrogels composed of both flexible polymer and stiff inorganic components are growing as interdisciplinary research materials that offer striking candidates for the design of injectable composite material towards bone tissue engineering. Indeed, the demands of bone regeneration or repair are increasing since population and average lifetime of human beings continue escalating. The incorporation of an inorganic constituent into the polymeric hydrogel matrix may afford ample mechanical strength, pioneer osteoconductive or osteoinductive properties and provides nucleation sites for in vivo bone formation [11,12]. The injectable hybrid hydrogels are being used in 3-D printing technology for tissue engineering with specific architectonics and properties because of the printing ability of the gels [13]. While the efficacy of 3-D bioprinting materials depends on the successful design of the in situ encapsulation of live cells into, and delivery of, bioactive molecules from materials [13]. However, for ideal tissue engineering, hydrogel scaffolds should contain enough porosity, interconnection channels for transport nutrients, biocompatibility, biodegradability and high mechanical strength [14,15]. Porous degradable scaffolds give a precise atmosphere for cells/tissue growth in vivo and vitro [14]. High porosity of scaffold facilitates attachment and proliferation of bone cells [16,17]. Macro size pores (pores $>100 \mu \mathrm{m}$ ) are recognized to contribute to osteogenesis by assisting cell and ion transport [18]. Micro size pores (pores $<20 \mu \mathrm{m}$ ) are considered to increase bone growth into scaffolds by affording connection positions for osteoblasts and mounting surface area for protein adsorption [19]. Additionally, high interconnectivities between pores are plenty for regular cell distribution when seeded [20].

Among the materials developed and employed for tissue engineering scaffolds, synthetic biodegradable polymers are imperative class of materials as their properties can eagerly be adapted by the control of the polymerization reaction [14,21]. But, the major disadvantage of the synthetic biodegradable polymer scaffolds is lack of the bioactivity [14]. In this aspect, hydrogel scaffolds fabricated from natural polymers have potential advantages-for instance biodegradability, biocompatibility, antithrombotic and hemostatic properties, incredible healing activity, water retention capacity, antibacterial activity, immunological property and are low-cost [14,22]. Among natural polymers, alginic acid (alginate, Alg) has been extensively used in the synthesis of hydrogels for biomedical applications owing to its biocompatibility, biodegradability and inexpensiveness [23]. Alg is an anionic polysaccharide composed of D-mannuronic acid (M block) and L-guluronic acid (G block) [23]. Mannuronic acid forms $\beta$-1,4-glycosidic linkages, while guluronic acid forms $\alpha$-1,4-glycosidic bonds. Alg has ability to form gels upon addition of multivalent ions [23]. Moreover, Alg is mucoadhesive, biocompatible and non-immunogenic making it very suitable for tissue engineering applications [23]. The Alg-based hydrogels have been comprehensively applied in drug/gene delivery, tissue engineering, wound healing, cell encapsulation and so on [24,25]. Alg hydrogel as scaffold for tissue engineering has distinctive advantages, for instance, they can be mixed with the cells in liquid form into the body to fill the damaged tissue and availability of three-dimensional space for cells growth [23]. Because of the high rate of degradation in cell culture and the weak mechanical properties, a single component Alg hydrogel restricts the practical application [23]. To overcome these issues, Alg has been modified - either physically or covalently — with a range of components such as gelatin, collagen, calcium phosphate, chitin whiskers, silica, grapheme oxide and bioglass to achieve hybrid materials with sufficient mechanical strength for drug delivery and different biological applications [13,23-36]. In recent years, bioceramics such as hydroxyapatite (HAp) and $\alpha$-tricalcium phosphate $(\alpha$-TCP) have often been employed with natural polymers for bone tissue regeneration because of the chemical resemblance of the materials to the mineral phase of bone [37,38]. Among the various bone prosthetic 
materials, TCP endures time-dependent absorption in vivo and is thus superior to HAp and other materials with low solubility in vivo regarding replacement by bone [39]. Moreover, the addition of $\alpha$-TCP not only amplifies the mechanical properties but also increases the osteoconductivity of the fabricated scaffolds, which is complimentary for bone tissue engineering [16,40].

Here, we report the development of a hybrid hydrogel of sodium alginate (Alg) and alpha tricalcium phosphate $(\alpha-\mathrm{TCP})$ particles. Three different compositions (10:1, 2:1 and 1:10 $w / w)$ have been prepared using $\alpha$-TCP at varying quantities in $6 \%$ Alg solutions using an ultrasonicator. To achieve regular distributions of bioceramics $(\alpha-\mathrm{TCP})$ and for better interfacial interaction between $\mathrm{Alg}$ and $\alpha-\mathrm{TCP}$, ultrasonicator has been applied. A self-hardening of scaffold is formed by crosslinking of Alg in presence of calcium chloride $\left(\mathrm{CaCl}_{2}\right)$ solution. The effects of $\mathrm{pH}$ and composition towards cellular responses and bioactive molecules release from ionically crosslinked hybrid gel (Alg- $\alpha$-TCP) have also been studied. The bovine serum albumin (BSA) as the model protein, tetracycline (TCN) as the model antibiotic, and dimethyloxalylglycine (DMOG) as the model angiogenic/osteogenic drug were in-situ incorporated into the hybrid gels and the in vitro release nature has been studied at $\mathrm{pH} 4,7$ and 7.4 at $37^{\circ} \mathrm{C}$. BSA has $76 \%$ sequence uniqueness with human serum albumin [41,42]. It is involved in various physiological activities like acid-base balance, transport and binding of numerous types of drugs and delivery of fatty acids [41-44]. DMOG is used to improve wound healing, attenuate post-ischemic myocardial injury and renal injury in remnant kidney [45]. It can increase angiogenic activity of bone marrow stromal cells and adipose derived stem cells via promoting the expression of hypoxia inducible factor- $-1 \alpha$ (HIF-1 $\alpha)$ and its downstream genes in cells to improve the angiogenesis of tissue-engineered bone [46]. While TCN shows anti-collagenase activity, inhibition of bone resorption, anti-inflammatory action and having capability to promote attachment of fibroblasts and connective tissue to root surfaces $[47,48]$. Finally, the ionic crosslinked Alg- $\alpha$-TCP hybrid gel, which is non-toxic and biocompatible against MC3T3 cells and executed controlled BSA, TCN and DMOG release ability, could be used as scaffold in bone tissue engineering.

\section{Materials and Methods}

\subsection{Materials}

Alginic acid (Alg) sodium salt from brown algae (medium viscosity), calcium chloride, calcium hydrogen phosphate dihydrate, calcium carbonate (purity $\geq 99 \%$ ), bovine serum albumin (BSA, molecular weight (MW) $\sim 66 \mathrm{kDa}$, lyophilized powder) and tetracycline (TCN, MW $444.43 \mathrm{Da}$, anhydrous basis) were purchased from Sigma Aldrich (St. Louis, MO, USA). Dimethyloxalylglycine (DMOG, MW $175.14 \mathrm{Da}$, purity $\geq 98 \%$ ) was purchased from Cayman Chemical Company (Ann Arbor, MI, USA). Double distilled water (DW) was employed for experimental purposes.

\subsection{Synthesis}

\subsubsection{Synthesis of $\alpha$-TCP by Ball Milling Machine}

The $\alpha$-TCP was prepared by the same protocol as described in our previous report [49]. Briefly, $100 \mathrm{~mL}$ ethanol was added to a molar mixer (2:1) of calcium hydrogen phosphate dihydrate $(68.84 \mathrm{~g})$ and calcium carbonate $(20.02 \mathrm{~g})$. The mixture was placed into a $500 \mathrm{~mL}$ alumina pot containing $100 \mathrm{~g}$ of zirconia particles $(d=5 \mathrm{~mm})$. It was then mixed in the ball milling machine (Model: SBML-2, SciLab Korea Co., Ltd., Seoul, Korea) at $150 \mathrm{rpm}$ for $24 \mathrm{~h}$. The zirconia particles were then recovered using a sieve (Daehan Scientific, Seoul, Korea) with $425 \mu \mathrm{m}$ pores. The dicalcium phosphate and calcium carbonate powders were then transferred to an aluminum tray and kept in a heating oven at $70{ }^{\circ} \mathrm{C}$ for $24 \mathrm{~h}$ for the removal of ethanol [49]. Afterwards, the powder containing alumina pot was heated up in an electrical furnace (Model: MHS-160526-01, MiR furnace, Seoul, Korea) at $1300{ }^{\circ} \mathrm{C}$ for $16 \mathrm{~h}$ using the provided program (escalation of heating for $2 \mathrm{~h}$ and heating for $16 \mathrm{~h}$ and then cooling). After cooling, clusters of $\alpha$-TCP particles were acquired. The $\alpha$-TCP clumps were transferred into an 
engineering plastic pot containing mixture of two kinds of zirconia particles ( $300 \mathrm{~g}$ with $d=20 \mathrm{~mm}$ and $100 \mathrm{~g}$ with $d=4 \mathrm{~mm}$ ) and $300 \mathrm{~mL}$ of ethanol. The plastic pot was loaded in the ball milling machine and rotated at room temperature for $24 \mathrm{~h}$ [49]. Finally, the dried $\alpha$-TCP particles were collected after evaporating of ethanol at $70{ }^{\circ} \mathrm{C}$ in a heating oven. The particle size of $\alpha$-TCP particle was measured by laser diffraction particle size analyzer (Model: LS I3 320, Beckman Coulter, Brea, CA, USA) and employed for hybrid gel formation.

\subsubsection{Preparation of Sodium Alginate (Alg) and $\alpha$-TCP Particles Hybrid Gel}

The hybrid gel of Alg and $\alpha$-TCP particles was fabricated by ionic crosslinking as follows: Firstly, sodium alginate $(0.3 \mathrm{~g})$ and $\alpha$-TCP particles $(0.03,0.15$ and $3.0 \mathrm{~g})$ were poured into $5 \mathrm{~mL}$ distilled water ( $\mathrm{pH} 7.0)$ in a $25 \mathrm{~mL}$ glass vial (Figure 1). After that, the components were mixed using the ultrasonicator (Vibra Cell, Sonics, Gyeonggi-do, Korea) to get a homogeneous slurry [49]. Then, a definite volume of blend $(0.3 \mathrm{~mL})$ was kept in an $8 \mathrm{~mL}$ Teflon sample vial $(d=10.3 \mathrm{~mm}$, Daihan Scientific, Seoul, Korea) and $0.1 \mathrm{M}$ calcium chloride $\left(\mathrm{CaCl}_{2}\right)$ solution was poured into the vial for ionic crosslinking. After that, the round shape gel was formed and taken out from calcium chloride solution. The gel samples were washed three times with distilled water $(3 \times 50 \mathrm{~mL})$ to remove excess calcium ions present in the surface of the gel. Finally, the gel mass was dried in a lyophilizer (IL Shin Lab, Gyeonggi-do, Korea) for $48 \mathrm{~h}$ at $-60^{\circ} \mathrm{C}$ and used for further study.

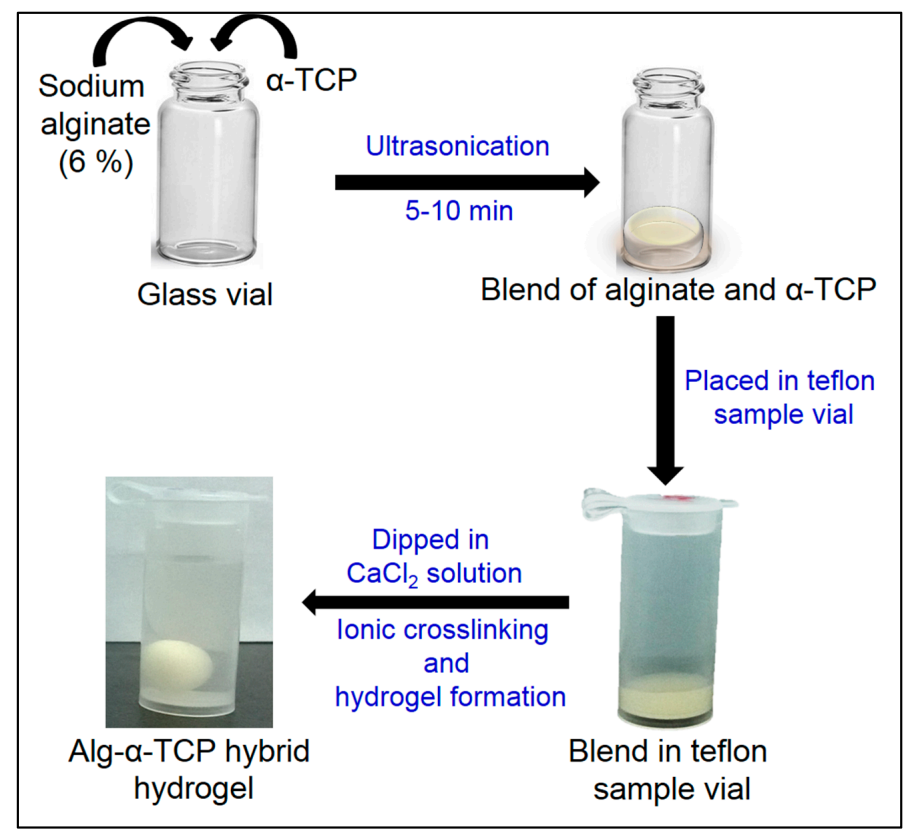

Figure 1. Schematic presentation of the fabrication process of Alg- $\alpha$-TCP hybrid gel.

\subsection{Determination of Ionic Concentration Dependent Gelation Time of Hybrid Gel}

The gelation times of the Alg- $\alpha$-TCP mixtures (10:1, 2:1 and 1:10 in $w / w)$ were measured by taking $0.3 \mathrm{~mL}$ slurry in the $8 \mathrm{~mL}$ Teflon sample vials $(d=10.3 \mathrm{~mm}$, Daihan Scientific, Seoul, Korea). To observe the effect of ionic concentration of $\mathrm{CaCl}_{2}$ on gelation time, different concentrations of calcium chloride solutions $(0.05,0.1,0.2,0.5$ and $1.0 \mathrm{M})$ were poured in the vials at room temperature $\left(25^{\circ} \mathrm{C}\right)$. Gelation phenomenon was visually observed when the slurry converted into round shape and detached from the bottom of the vials.

\subsection{Characterizations}

The attenuated total reflectance Fourier transform infrared (ATR-FTIR) spectra of sodium alginate, $\alpha$-TCP and dried hybrid gels (10:1, 2:1 and 1:10 in $w / w)$ were recorded using an ATR-FTIR spectrometer 
(Model: Travel IR, Smiths Detection, Edgewood, WI, USA). The wavelength range of spectra were $650-4000 \mathrm{~cm}^{-1}$. The surface morphology of $\alpha$-TCP and the dried hybrid gels (10:1, 2:1 and 1:10) were observed using scanning electron microscopy (Model: SEM, TESCAN VEGA3, Tescan, Seoul, Korea). The particle size of $\alpha$-TCP was determined using a laser diffraction particle size analyzer (Model: LS I3 320, Beckman Coulter, Brea, CA, USA) at solid state. The powder X-ray diffraction (XRD) analysis of $\alpha$-TCP was carried out using X-ray diffractometer (Model: Bruker DE/D8 Advance, Bruker AXS GmbH, Karlsruhe, Germany). The step size was $0.02^{\circ}$, time per step was $0.1 \mathrm{~s}$. The range of $2 \theta$ was $5^{\circ}-80^{\circ}$. The calcium content of the $\operatorname{Alg}-\alpha$-TCP $(10: 1,2: 1$ and 1:10) hybrid gels was measured by inductively coupled plasma mass spectrometry (ICP-MS) (Model: iCAP Q, ThermoFisher Scientific, Bremen, Germany).

\subsection{Determination of Calcium Content in Alg- $\alpha$-TCP Hybrid Gels}

The calcium (Ca) content in the Alg- $\alpha$-TCP (10:1, 2:1 and 1:10) hybrid gels were measured by inductively coupled plasma mass spectrometry (ICP-MS) (Model: iCAP Q, ThermoFisher Scientific, Bremen, Germany). A known amount $(0.05 \mathrm{~g})$ of each dried gel was treated with $70 \%$ nitric acid $\left(\mathrm{HNO}_{3}\right)$ solution for 2 days at $110{ }^{\circ} \mathrm{C}$ for the formation of water soluble calcium nitrate compound. After that, the solutions were filtered. The filtrates were transferred in different $50 \mathrm{~mL}$ volumetric flasks and the volume was make up by distilled water. The calcium content in each solution was determined three times by inductively coupled plasma mass spectrometer (Model: iCAP Q, ThermoFisher Scientific, Bremen, Germany). The average concentration of the $\mathrm{Ca}$ in the solution is expressed in parts per billion $(\mathrm{ppb}, \mu \mathrm{g} / \mathrm{L})$.

\subsection{Swelling Study}

The \% swelling of the hybrid gels (10:1, 2:1 and 1:10 in $w / w)$ were measured at $\mathrm{pH} 4,7$ and 7.4 and $37^{\circ} \mathrm{C}$. In brief, the pre-weighed dried hybrid gels $(0.25 \mathrm{~g})$ were immersed in $50 \mathrm{~mL}$ different buffers ( $\mathrm{pH} \mathrm{4,7}$ and 7.4) for $12 \mathrm{~h}$. After regular time interval $(1 \mathrm{~h})$, the swollen gels were taken out from distilled water and the surface water was blotted off by tissue paper. The hydrogels were then reweighed until constant weights were attained. The \% swelling was calculated by the Equation (1):

$$
\text { Swelling }(\%)=\frac{\text { Final weight of hybrid gel }- \text { Initial weight of dried hybrid gel }}{\text { Initial weight of dried hybrid gel }} \times 100
$$

\subsection{MC3T3 Cell Viability inside the Alg- $\alpha$-TCP Hybrid Gel}

An osteoblast cell line derived from Mus musculus (mouse) calvaria (MC3T3, Sigma Aldrich Sigma Aldrich Co., St. Louis, MO, USA) was in vitro cultured in alpha minimum essential medium ( $\alpha$-MEM) containing both $10 \%$ fetal bovine serum (Gibco Korea, Seoul, Korea) and penicillin-streptomycin (100 unit $/ \mathrm{mL}$ ) in an incubator with $5 \% \mathrm{CO}_{2}$ at $37^{\circ} \mathrm{C}$. At first, Alg- $\alpha$-TCP hybrid mixtures (10:1, 2:1 and 1:10) were sterilized by autoclave (AC-02, Jeio Tech; Seoul, Korea). After wards, the MC3T3 cells were put on the surface of $0.2 \mathrm{~mL}$ blends at a density of $1 \times 10^{4}$ cells $/ \mathrm{mL}$ in 24 well plates by syringe and incubated for $5 \mathrm{~min}$. After that, the cells were covered by additional $0.2 \mathrm{~mL}$ of blends. Next, $100 \mu \mathrm{L}$ mixture (9:1) of $\alpha$-MEM media and $0.1 \mathrm{M} \mathrm{CaCl}_{2}$ solution was added two times in each well for $20 \mathrm{~min}$. Again, $100 \mu \mathrm{L}$ mixture (9:1) of $\alpha$-MEM media and $0.1 \mathrm{M} \mathrm{CaCl}_{2}$ solution was added in each well for $15 \mathrm{~min}$ to form hybrid gel. After removing mix solution from wells, the hybrid gels were washed 3 times with phosphate buffered saline ( $\mathrm{pH}$ 7.4) for $3 \mathrm{~min}$. Subsequently, $1.5 \mathrm{~mL}$ of $\alpha$-MEM media was supplied to each well and changed after $24 \mathrm{~h}$. The cells inside of the hybrid gels were cultured up to 10 days. To observe the effect of $\mathrm{pH}$ on proliferation and viability, cell study was performed at $\mathrm{pH}$ 7.0 and 7.4.

Assay of live and dead viability for mammalian cells was carried out following the protocol of the vendor (Invitrogen, Carlsbad, CA, USA). Both $1.2 \mu \mathrm{L}$ of $2 \mathrm{mM}$ ethidium homodimer-1 (EthD-1) and $0.3 \mu \mathrm{L}$ of $4 \mathrm{mM}$ calcein-acetoxymethyl ester (Calcein AM) were added into $600 \mu \mathrm{L}$ phosphate buffer saline (PBS). After addition of the prepared agents to each well and $30 \mathrm{~min}$ of incubation, 
the images of the cells inside the hybrid gels were captured by fluorescence microscope (Leica DMLB, Wetzlar, Germany).

\subsection{Cytotoxicity Study of Alg- $\alpha$-TCP Hybrid Gel Using MTT, Brd U and Neutral Red Assays}

The cytotoxicity study was performed with the thiazolyl blue tetrazolium bromide (MTT assay), bromodeoxyuridine (BrdU) assay and neutral red assay. The method is described in below:

\subsubsection{MTT Assay}

After seeding $1 \times 10^{4}$ no. of MC3T3 cells in a 96 well-plate, the samples were incubated in an incubator with $5 \% \mathrm{CO}_{2}$ atmosphere at $37^{\circ} \mathrm{C}$ for $24 \mathrm{~h}$. Afterwards, medium was removed and $100 \mathrm{~mL}$ each extracted solutions of positive control Teflon, negative control latex $\left(1 \times 1 \mathrm{~cm}^{2}\right)$ and three hybrid gels (10:1, 2:1 and 1:10) were added into each cell well and cultured for another $24 \mathrm{~h}$. Next, $20 \mu \mathrm{L}$ MTT solution ( $2 \mathrm{mg} / \mathrm{mL}$ in PBS) was added in the culture medium and lasted for another $4 \mathrm{~h}$. Then, medium was removed and $100 \mu \mathrm{L}$ dimethyl sulfoxide (DMSO) was poured. The optical density of the final solution was measured by microplate reader at the wavelength of $570 \mathrm{~nm}$.

\subsubsection{BrdU Assay}

The same protocol was followed for the culture of MC3T3 cells and mixing of five extracted solutions as performed above for MTT assay. After that, $10 \mu \mathrm{L}$ BrdU labeling solution was added into the culture medium and kept in the incubator for another $2 \mathrm{~h}$. Then, $200 \mu \mathrm{L}$ Fixodent solution and $100 \mu \mathrm{L}$ anti-BrdU peroxide-labeled anti-BrdU antibody were added to each well according to the manufacturer's protocol. After washing the wells, $25 \mu \mathrm{L} 1.0 \mathrm{M} \mathrm{H}_{2} \mathrm{SO}_{4}$ solution was added into each well. The optical density of the samples was measured by microplate reader at the wavelength of $450 \mathrm{~nm}$ with the reference of $690 \mathrm{~nm}$.

\subsubsection{Neutral Red Assay}

After cultured of MC3T3 cells for $24 \mathrm{~h}$, the addition of five kinds of extracted solutions of Teflon, latex and three hybrid gels (10:1,2:1 and 1:10) was performed according to same procedure as described above for MTT and BrdU assays. Subsequently, the mixture of the culture medium and $0.33 \%$ neutral red solution (9:1) were added into the well plate and the cell culture was lasted for another $2 \mathrm{~h}$ in the incubator. After $10 \mathrm{~min}$ of washing with the fixation solution, $100 \mu \mathrm{L}$ solubilizing solution was added into each well. The optical density was measured at the wavelength of $550 \mathrm{~nm}$ by microplate reader (Tecan GENios FL., GMI, Brooklyn Park, MN, USA) with the reference of $690 \mathrm{~nm}$.

\subsection{In-Situ Encapsulation of Protein (BSA) and Drugs (TCN and DMOG) into Hybrid Gel}

The in situ incorporation of bovine serum albumin (BSA), tetracycline (TCN) and dimethyloxalylglycine (DMOG) into different grades of hybrid gel were performed at room temperature $\left(25^{\circ} \mathrm{C}\right)$ using distilled water as media $(\mathrm{pH} 7.0)$ using the ultrasonicator. For this experiment, the same mole of BSA, TCN and DMOG $\left(4.95 \times 10^{-6} \mathrm{~mol}\right)$ were homogeneously mixed with different ratios (10:1, 2:1 and 1:10) of $\mathrm{Alg} / \alpha$-TCP $(0.165 \mathrm{~g})$ and then put into $8 \mathrm{~mL}$ Teflon sample vial $\left(d=10.3 \mathrm{~mm}\right.$, Daihan Scientific, Seoul, Korea). After that, $0.1 \mathrm{M} \mathrm{CaCl}_{2}$ solution was added and kept $30 \mathrm{~min}$ for crosslinking and round shape gel formation. After that, protein and drugs incorporated gel beads were dried in lyophilizer for $48 \mathrm{~h}$ and used for release study.

\subsection{In Vitro Protein and Drugs Release Study}

The in vitro release study of BSA, TCN and DMOG incorporated hybrid gels were executed in different buffers ( $\mathrm{pH} 4,7$ and 7.4) at $37^{\circ} \mathrm{C}$. The BSA, TCN and DMOG release were determined spectrophotometrically using a UV-Vis spectrophotometer (BioMate 3S, ThermoScientific, Madison, WI, USA). Briefly, dried BSA, TCN and DMOG incorporated gels were kept in $10 \mathrm{~mL}$ distilled water into 
$25 \mathrm{~mL}$ screw Teflon bottles (Daihan Scientific, Seoul, Korea). After definite intervals, the solutions were taken out from the Teflon bottles and the spectra were recorded. After each measurement, the solutions were returned back to the bottles. On the basis of standard solutions, percentage of BSA, TCN and DMOG were calculated.

\subsection{Statistical Analysis}

All data were expressed as mean \pm standard deviations. Statistical significance was assessed with one-way and multi-way ANOVA by employing the SPSS 18.0 program (ver. 18.0, SPSS Inc., Chicago, IL, USA). The comparisons between two groups were carried out, using $t$-test and the samples were considered as significantly different when $p<0.05$.

\section{Results and Discussion}

\subsection{Synthesis of $\alpha-T C P$ Particles}

Wet milling process was applied for the synthesis of $\alpha$-TCP particles using solid precursors (calcium hydrogen phosphate dihydrate and $\mathrm{CaCO}_{3}$ ) in ethanol at $130{ }^{\circ} \mathrm{C}$. The precursors were milled concurrently to make small particles by improving the contact space [50]. At $1300{ }^{\circ} \mathrm{C}$, dicalcium hydrogen phosphate reacted with calcium carbonate and formed TCP as describe in Equation (2) [50].

$$
2\left[\mathrm{CaHPO}_{4} \cdot 2 \mathrm{H}_{2} \mathrm{O}\right]+\mathrm{CaCO}_{3}=\mathrm{Ca}_{3}\left(\mathrm{PO}_{4}\right)_{2}+\mathrm{CO}_{2}+5 \mathrm{H}_{2} \mathrm{O}
$$

The size of synthesized $\alpha$-TCP particles has been determined by laser diffraction micro-particle size analyzer. The result is depicted in Figure 2a. It is obvious that the particle sizes of the $\alpha$-TCP remain between 0.5 and $10 \mu \mathrm{m}$. The SEM image of the $\alpha$-TCP particles (Figure $2 \mathrm{~b}$ ) suggests that different shaped $\alpha$-TCP particles formed, while particle sizes remain within micrometer range. Figure $2 c$ depicts the XRD spectra of the synthesized $\alpha$-TCP particles and standard JCPDS card 9-348 of alpha TCP [51]. From Figure 2c, it is observed that the major diffraction peak of $\alpha$-TCP appeared at $2 \theta=31^{\circ}$, which is well matched with the major diffraction peak of JCPDS card 9-348 of alpha TCP, confirming the formation of $\alpha$-TCP.

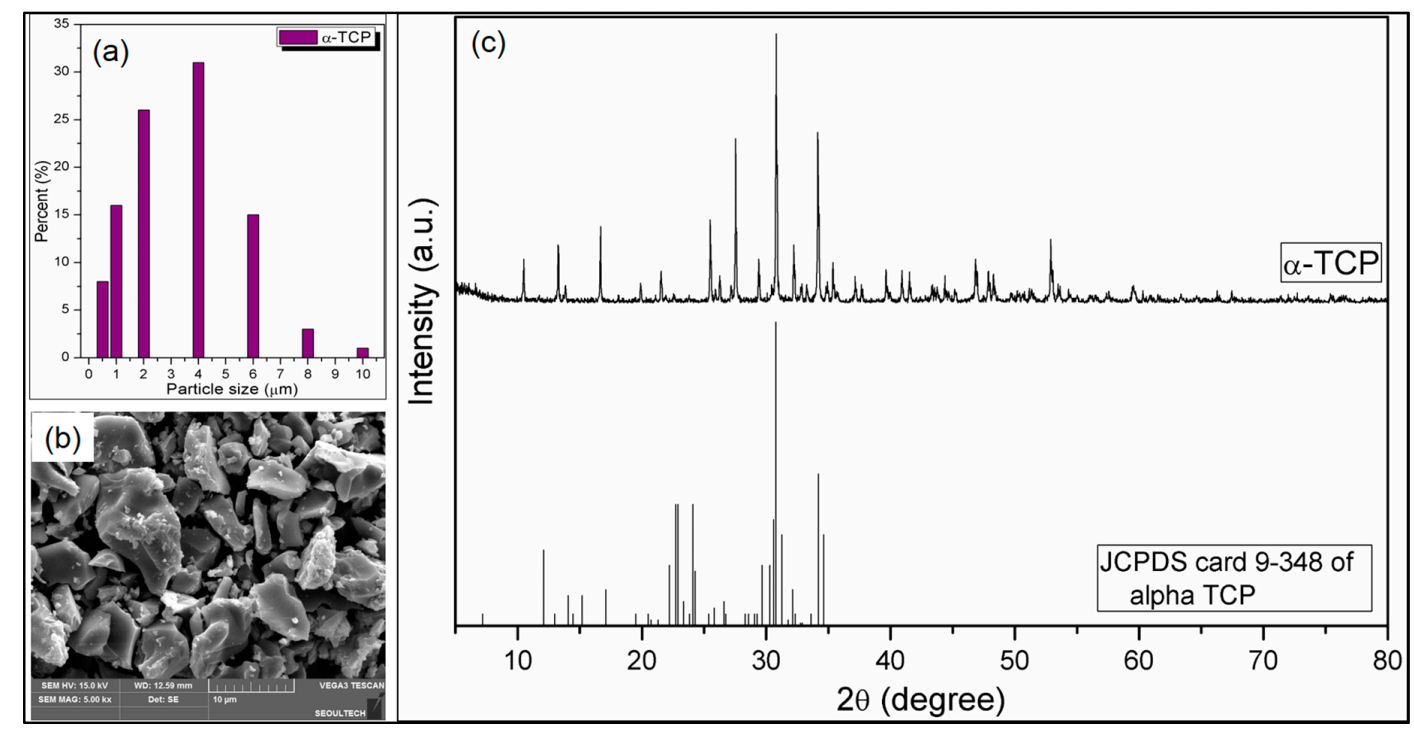

Figure 2. (a) Size distributions of the synthesized $\alpha$-TCP particles obtained from laser diffraction micro-particle size analyzer; (b) Scanning electron microscopy (SEM) image of the synthesized $\alpha$-TCP particles; (c) X-ray diffraction (XRD) spectra of the synthesized $\alpha$-TCP particles and JCPDS card 9-348 of alpha TCP. 


\subsection{Fabrication of Alg- $\alpha$-TCP Hybrid Gel}

The ionic cross-linked Alg- $\alpha$-TCP gel has been synthesized using a slurry of Alg and $\alpha$-TCP, which has been prepared by ultrasonication and then $\mathrm{CaCl}_{2}$ used for crosslinking reaction. The fabrication procedure and mechanism are represented in Figures 1 and 3, respectively. In $\alpha-\mathrm{TCP}, \mathrm{Ca}^{2+}$ and $\mathrm{PO}_{4}{ }^{3-}$ form unit cells of $\alpha$-TCP where, two kinds of columns are present: (i) $\mathrm{Ca}^{2+}$ cations columns (C-C) and (ii) $\mathrm{Ca}^{2+}$ cations and $\mathrm{PO}_{4}{ }^{3-}$ anions columns (C-A). Each C-C column is surrounded by six C-A columns [50]. Here, ultra-sonication method has been applied for the homogeneous distribution $\alpha$-TCP particles in the Alg network and to improve the area of contact for attachment of ceramic particles in the Alg network. In presence of $\mathrm{CaCl}_{2}$, the $-\mathrm{COO}^{-}$groups of $\mathrm{Alg}$ crosslinked with $\mathrm{Ca}^{2+}$ ions through electrostatic interaction and form ionic cross-linked Alg- $\alpha$-TCP gel (Figure 3). In presence of cross-linker $\left(\mathrm{Ca}^{2+}\right)$, alginate moieties connect with each other through cooperative mechanism and form "egg-box" pattern $[49,52]$. Basically, the divalent cations $\left(\mathrm{Ca}^{2+}\right)$ connect alginate chains via ionic interaction and make interconnected layers around the eggs box [49,52].

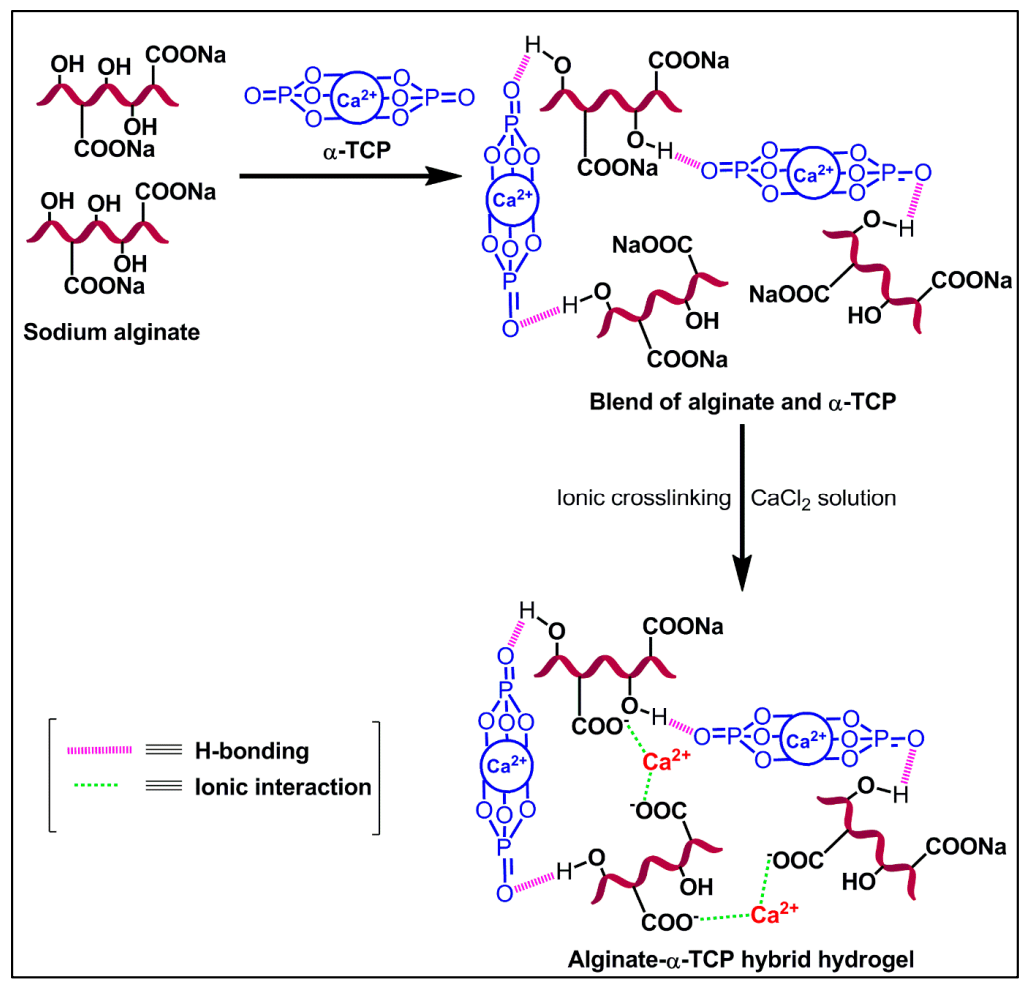

Figure 3. Schematic of probable reaction mechanism for Alg- $\alpha$-TCP hybrid gel formation.

\subsection{Effect of $\alpha$-TCP Particles and Ionic Concentration $\left(\mathrm{CaCl}_{2}\right)$ on Gel Formation}

To observe the effects of composition of the hybrid gel on gel formation, three grades of Alg/ $\alpha$-TCP slurry (10:1, 2:1 and 1:10 $w / w)$ have been prepared by changing the number of $\alpha$-TCP particles in $6 \%$ Alg solution. Gelation has been visibly observed when the slurry formed round shaped gel masses in the $0.05,0.1,0.2,0.5$ and $1.0 \mathrm{M}$ of $\mathrm{CaCl}_{2}$ solutions. With progress of time, slurry became hard and formed round shape, which is because of the crosslinking reaction between Alg and $\alpha$-TCP. After completion of the crosslinking, gel mass detached from the bottom of the Teflon vials. Time has been measured by stop watch. It has been observed that with increase of $\alpha$-TCP particles gelation time decreased (Figure $4 \mathrm{~A}$ ) in all concentration of $\mathrm{CaCl}_{2}$ solutions. For the 10:1 mixture, the gelation time is less than that of 2:1 and 1:10 mixtures. In the 10:1 system, the number of $\alpha$-TCP particles is less and as a consequence the diffusion of $\mathrm{Ca}^{2+}$ ions into the hybrid system is easier compared to those of 2:1 and 1:10 systems. Therefore, $\mathrm{Ca}^{2+}$ ions can quickly enter into the system and formed ionic cross-linked 
network. While in the cases of the 2:1 and 1:10 systems, the presence of higher amount of $\alpha$-TCP particles create a barrier for the diffusion of $\mathrm{Ca}^{2+}$ ions. Consequently, for the diffusion of $\mathrm{Ca}^{2+}$ ions into the 2:1 and 10:1 hybrid systems longer time is required than that of 10:1 system. Thus, the gelation time of the Alg: $\alpha$-TCP hybrid gel follows the order: 10:1 > 2:1 > 1:10.
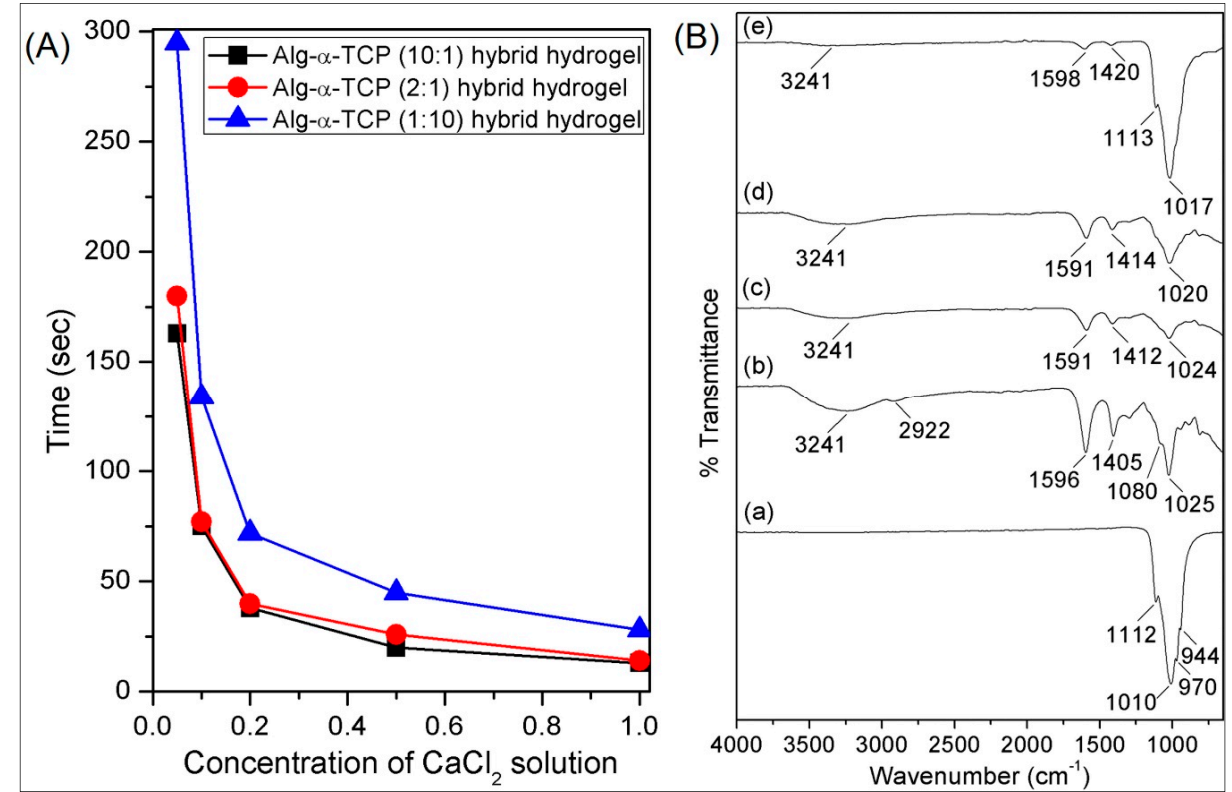

Figure 4. (A) Gelation time of Alg- $\alpha$-TCP (10:1, 2:1 and 1:10) hybrid gels at different concentrations of $\mathrm{CaCl}_{2}$ solutions $[\mathrm{M}]$ and (B) attenuated total reflectance Fourier transform infrared (ATR-FTIR) spectra of dried (a) $\alpha-\mathrm{TCP},(\mathbf{b})$ sodium alginate and hybrid gel with different compositions (c) 10:1, (d) 2:1 and (e) 1:10.

From the Figure $4 \mathrm{~A}$, it is also noticed that gelation time decreases with increase of ionic concentrations of $\mathrm{CaCl}_{2}$. This is due to the fact that the availability of greater numbers of $\mathrm{Ca}^{2+}$ ions at higher concentration of $\mathrm{CaCl}_{2}$ solution assisted quicker crosslinking process compared to that of lower concentration of $\mathrm{CaCl}_{2}$ solution. Hence, the order follows is: $0.05 \mathrm{M}<0.1 \mathrm{M}<0.2 \mathrm{M}<0.5 \mathrm{M}<$ 1.0 M. Here, $0.1 \mathrm{M} \mathrm{CaCl}_{2}$ has been selected for the whole experiment.

\subsection{Characterizations}

In the FTIR spectrum of $\alpha$-TCP (Figure 4B(a)), the peaks at 1112, 1010, 970 and $944 \mathrm{~cm}^{-1}$ are due to the asymmetric and symmetric stretching vibrations of $\mathrm{P}-\mathrm{O}$ bonds, respectively [42]. In the FTIR spectrum of Alg (Figure 4B(b)), the peaks at 3241, 1596, 1405, 1080 and $1025 \mathrm{~cm}^{-1}$ are because of the $-\mathrm{OH}$ stretching, stretching of carboxylate groups $(\mathrm{C}=\mathrm{O},-\mathrm{C}-\mathrm{O})$, asymmetric and symmetric stretching of $\mathrm{C}-\mathrm{O}-\mathrm{C}$ bond, respectively [42]. The FTIR spectra of the dried Alg- $\alpha$-TCP $(1: 10,2: 1$ and 1:10) hybrid gels are depicts in Figure $4 \mathrm{~B}(\mathrm{c}-\mathrm{e})$. For all hydrogels (Figure $4 \mathrm{~B}(\mathrm{c}-\mathrm{e})$ ), it is obvious that the intensities of the stretching vibrations of carboxylate group (1596 and $1405 \mathrm{~cm}^{-1}$ ) decreased which are because of the ionic crosslinking between the carboxylate groups of Alg and $\mathrm{Ca}^{2+}$ ions (Figure 3) [42]. Moreover, the progressive broadness of $-\mathrm{OH}$ stretching vibration $\left(3241 \mathrm{~cm}^{-1}\right)$ indicates that there is a physical interaction (H-bonding) between $\alpha$-TCP particles and Alg (Figure 4B(c-e)).

Figure 5 describes the surface morphology of the dried hybrid gels at different ratios (10:1, 2:1 and 1:10) of Alg and $\alpha$-TCP. After incorporation of $\alpha$-TCP particles and ionic crosslinking, the morphology of alginate changed and the hybrid gels appeared with rough surface (Figure $5 \mathrm{a}-\mathrm{c}$ ). It is also noticed that the $\alpha$-TCP particles are distributed on the Alg surface (Figure 5a-c). In the 1:10 hybrid hydrogel (Figure 5c), $\alpha$-TCP particles are agglomerated in the surface and formed comparatively roughest surface among all samples. From the cross-section images (Figure $5 d-f$ ), it is observed that hydrogels 
are porous and porosity depends on the compositions. It is also noticed that the $\alpha$-TCP particles are not only distributed on the surface of the hydrogel but also fully incorporated into the hydrogel network (Figure 5d-f). The regular distribution of $\alpha$-TCP particles into the Alg network could improve the interfacial interaction between Alg and $\alpha$-TCP which may increase the mechanical strength of the hybrid gel. The high density of $\alpha$-TCP particles in 1:10 system form agglomeration and which results smaller pore sizes.

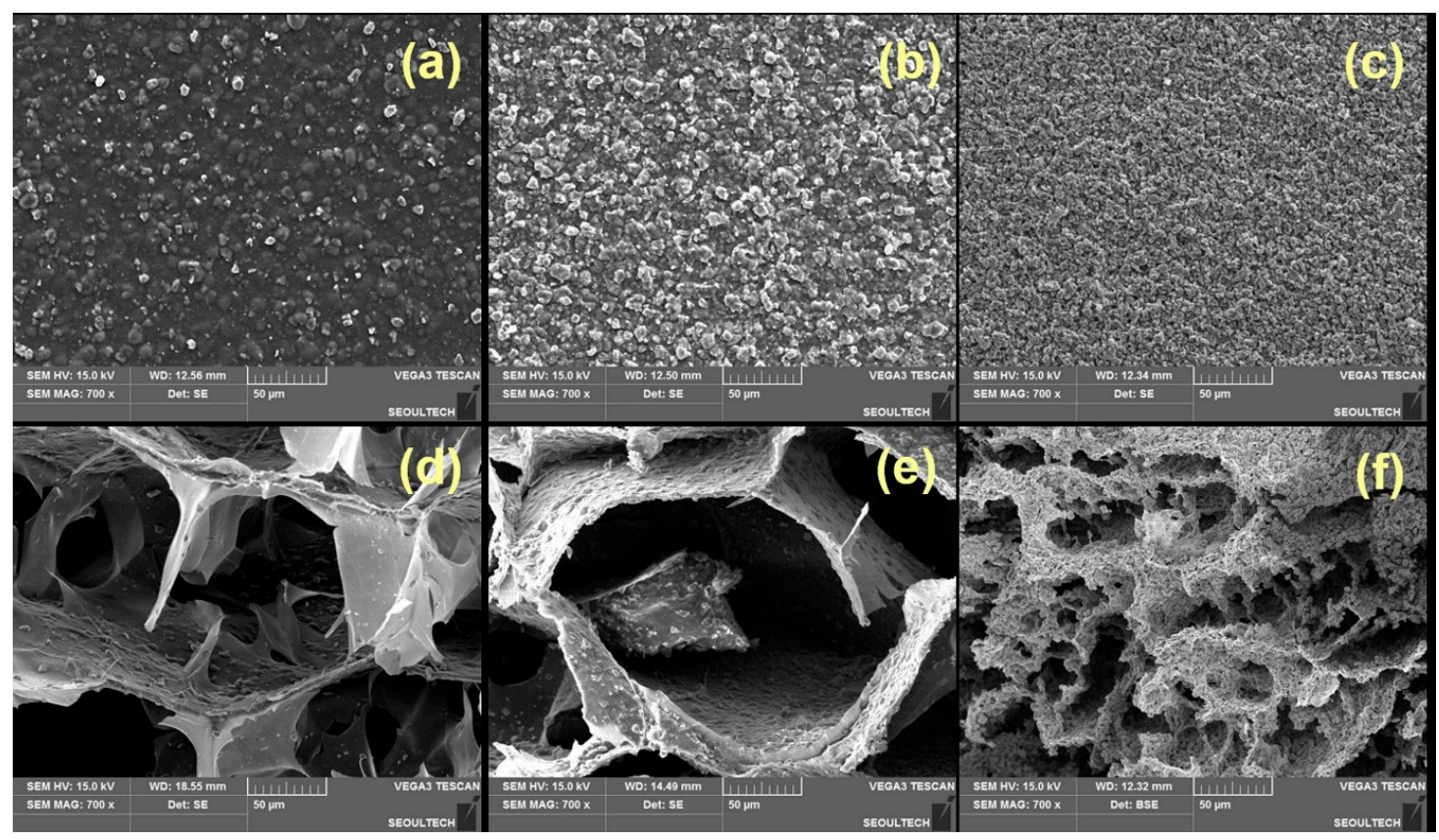

Figure 5. Surface $(\mathbf{a}-\mathbf{c})$ and cross-section images of dried Alg- $\alpha$-TCP hybrid gels with different compositions (d) 10:1, (e) 2:1 and (f) 1:10.

\subsection{Determination of Calcium Content in Alg- $\alpha$-TCP Hybrid Gels}

The calcium (Ca) content in the Alg- $\alpha$-TCP hybrid gels have been measured after treating with $70 \%$ nitric acid $\left(\mathrm{HNO}_{3}\right)$ solution by inductively coupled plasma mass spectrometry (ICP-MS). It has been observed that the average concentrations of $\mathrm{Ca}$ in the nitric acid treated solutions of dried Alg- $\alpha$-TCP (10:1, 2:1 and 1:10) gels were 12,581,000, 21,924,500 and 44,028,500 ppb ( $\mu \mathrm{g} / \mathrm{L})$, respectively.

\subsection{Swelling Study}

Figure 6 describes swelling tests results of the Alg- $\alpha$-TCP (10:1, 2:1 and 1:10) hybrid gels in different $\mathrm{pH}(4,7$ and 7.4$)$ at $37^{\circ} \mathrm{C}$, where gels attained equilibrium swelling state at $\sim 10 \mathrm{~h}$. It is noticed that \% swelling of the 10:1 hybrid gel is higher than those of 2:1 and 1:10 hybrid gels. The phenomena could be explained by the fact that swelling of the hybrid gels depend on the existence and availability of functional hydrophilic groups, crosslinking density and distribution of the filler ( $\alpha$-TCP) into the hybrid gels [49]. For the 10:1 hybrid gel, lower amount of $\alpha$-TCP is present, while it is highest for the 1:10 hybrid gel. The higher $\% \alpha$-TCP decreased the void space in the gel network and created smaller sizes of pores. This is also noticed in the cross-section images of the hybrid gels (Figure $5 \mathrm{~d}-\mathrm{f}$ ). For this reason, the diffusion of water molecules is lowest for 1:10 hybrid gel, compared to those of 2:1 and 10:1 system. Again, from the ATR-FTIR spectra (Figure 4B-b-d), it is observed that the -OH groups are connected by the physical interactions with $\alpha$-TCP particles. Thus, the availability of hydrophilic -OH groups (which can bind water molecules during swelling) are highest in case of the 10:1 hybrid gel and lowest for the 1:10 hybrid gel. Hence, the \% swelling of the hybrid gels followed the order is: $10: 1>2: 1>1: 10$. 


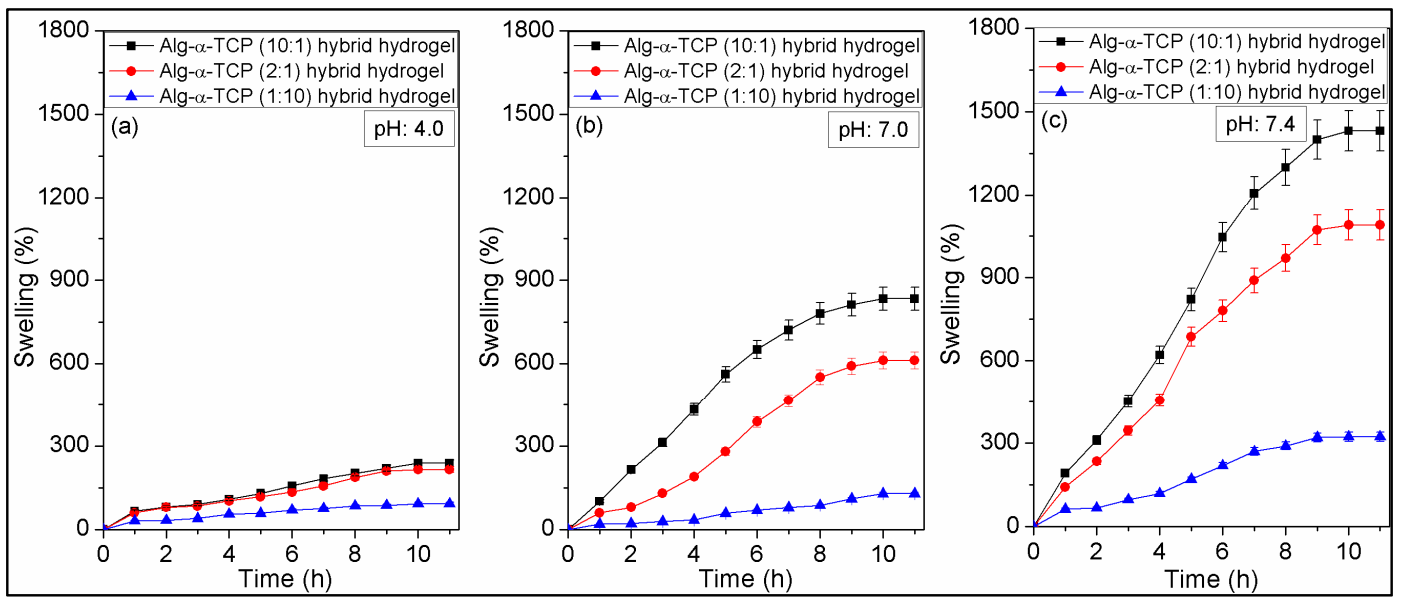

Figure 6. Swelling behaviors of Alg- $\alpha$-TCP (10:1, 2:1 and 1:10) hybrid gels at (a) pH 4.0; (b) pH 7.0; (c) $\mathrm{pH} 7.4$ and $37^{\circ} \mathrm{C}$.

The effect of $\mathrm{pH}$ on the swelling behavior of the Alg- $\alpha$-TCP (10:1, 2:1 and 1:10) hybrid gels is also obvious from Figure 6. It is observed that \% swelling is higher at basic medium ( $\mathrm{pH} 7.4$ ) and lower at acidic medium ( $\mathrm{pH} 4$ ). For example, the \% swelling of 10:1 hybrid gel was $92 \pm 4 \%$ at $\mathrm{pH} 4$, $128 \pm 6 \%$ at $\mathrm{pH} 7$ and $323 \pm 16 \%$ at $\mathrm{pH} 7.4$. The results are may be because of the fact that acidic medium (pH 4, Figure 6a), the charge density on hybrid gel decreased as the unreacted carboxylate ions protonated (generally $\mathrm{G}$ units form ionic crosslinking with $\mathrm{Ca}^{2+}$ ) [24]. Therefore, the hydrophilicity of the hydrogel decreased at acidic medium, resulting lower \% swelling. While at $\mathrm{pH} 7$, no such changes occurred, the crosslinked network remain as integral network. On the other hand, at PBS ( $\mathrm{pH}$ 7.4), the crosslinking agent $\left(\mathrm{Ca}^{2+}\right.$ ion) takes part in complexation reaction with the ions present in the medium and may form $\mathrm{Ca}_{3}\left(\mathrm{PO}_{4}\right)_{2}$ or $\mathrm{Ca}(\mathrm{OH})_{2}$ as precipitation. In this case, with progress of time, turbidity in the solution has been noticed. Thus, crosslinking density reduced at $\mathrm{pH} 7.4$, which assisted more water absorption. Moreover, at $\mathrm{pH}$ 7.4, the unreacted carboxylate ions repulse each other which offers more space for the diffusion of water into the crosslinked network. The weight loss of hybrid gel has been observed at $\mathrm{pH} 7.4$ after $12 \mathrm{~h}$. This is may be because of the breakdown of total ionic crosslinking. Hence, the \% swelling follows the order at different $\mathrm{pH}$ is: $\mathrm{pH} 7.4>\mathrm{pH} 7.0>\mathrm{pH}$ 4.0.

It is reported that $\alpha$-TCP hydrates after immersion in aqueous media even at $37^{\circ} \mathrm{C}$ and forms calcium-deficient hydroxyapatite (CDHAp) [53,54]. The rate of $\alpha$-TCP hydration also increased with temperature and decreased with increasing $\mathrm{pH}$ of the medium [53]. Heat is evolved during the conversion of $\alpha$-TCP and setting take place [53]. At the initial stage, heat evolution rate is higher and later stage it is lower [53]. The conversion results small crystalline microstructure plate which are interconnected to each other [53]. It is also reported that the orientation of the plate was perpendicular to $\alpha$-TCP which allows ion transport and do not retard the rate of hydrolysis [53]. The evolution of heat during the transformation process, the particle size and orientation of CDHAp may affect the swelling characteristics of the hydrogel. Due to evolution of heat, the mobility of the water molecule will be increased which may cause faster swelling at the initial stage than later stage. Furthermore, owing to the formation of smaller size CDHAp, the porosity into the hydrogel network will decrease which results slower rate of water diffusion into the hydrogel network in the later stage than that of initial stage.

\subsection{MC3T3 Cell Responses to the Hybrid Gel}

Figure 7 shows the fluorescence microscopy images of the live and dead MC3T3 cells (passage $(p)=12)$ inside the Alg- $\alpha$-TCP $(10: 1,2: 1$ and 1:10) hybrid gels at $\mathrm{pH} 7,7.4$ after 1 and 5 days. It is observed that all the cells were alive inside the hybrid gels after 1 day (Figure 7). However, few numbers of dead cells are obvious in each case after 5 days than that of day 1 . The in vitro MC3T3 cell proliferation inside the Alg- $\alpha$-TCP hybrid gels at different $\mathrm{pH}$ was measured up to 10 days by 
normalizing the cells number with day 1 . From the proliferation plots (Figure $8 \mathrm{a}-\mathrm{c}$ ), it is obvious that the rate of cell proliferation increased up to 7 days but at 10 days the rate decreased. This result may be because of the unavailability of space for further cells grow inside the hydrogel. The rate of cell proliferation is higher at $\mathrm{pH} 7.4$ compared to $\mathrm{pH} 7$ (Figure 8c). At basic medium ( $\mathrm{pH} 7.4$ ), the free carboxylate ions of the hybrid gel create repulsive force and stretch the network. Consequently, the space for MC3T3 cells attachment and proliferation is enhanced (Figure 8a-c). The above results indicate that MC3T3 cells are viable inside the Alg- $\alpha$-TCP hybrid gel network.
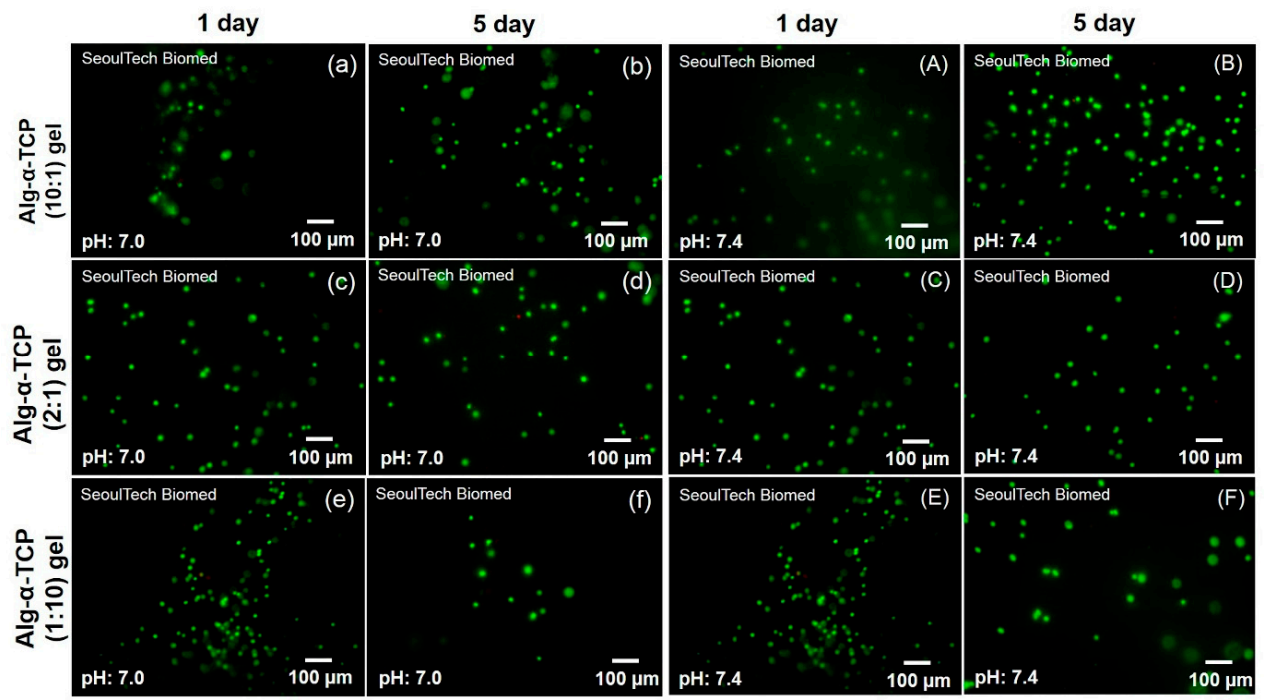

Figure 7. Fluorescence microscopy images of the live and dead MC3T3 cells inside the Alg- $\alpha$-TCP hybrid gels (1:10, 2:1 and 10:1) at pH $7.0(\mathbf{a}-\mathbf{f})$ and pH $7.4(\mathbf{A}-\mathbf{F})$ using Calcein AM and EthD-1 kits.

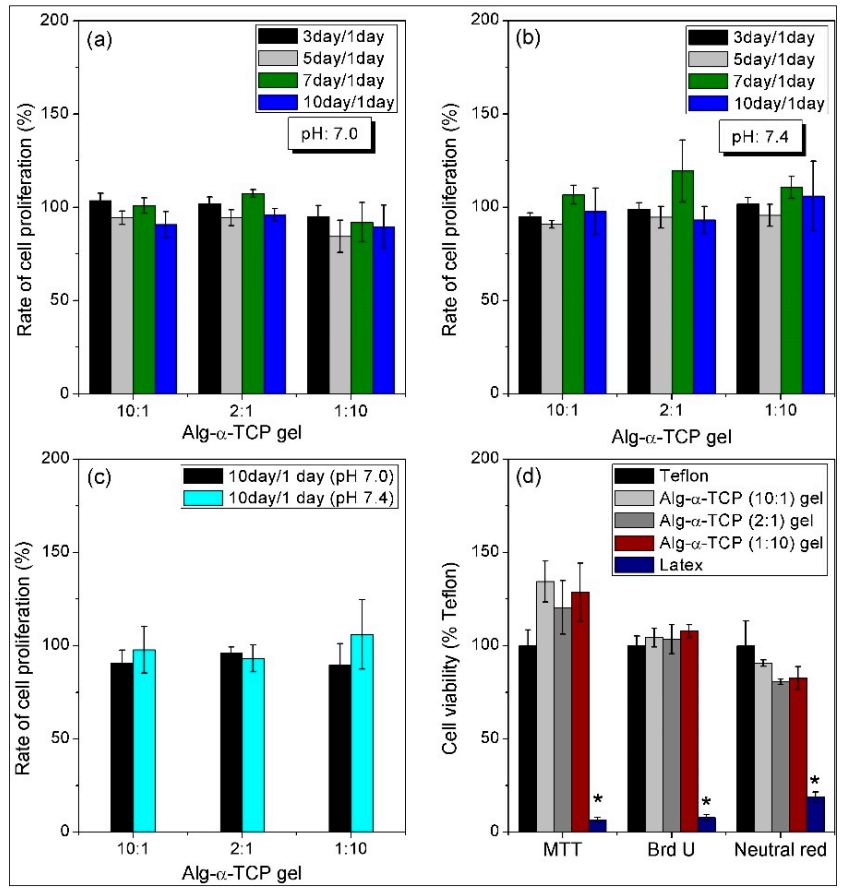

Figure 8. Rate of MC3T3 cell proliferation inside the Alg- $\alpha$-TCP (10:1, 2:1 and 1:10) gels at (a) pH 7.0; (b) $\mathrm{pH} 7.4$; (c) comparative study of cell proliferation at $\mathrm{pH} 7.0$ and $\mathrm{pH} 7.4$ after 10 days and (d) cytotoxicity of hybrid gels by the MTT, BrdU and Neutral red assays. 


\subsection{Cytotoxicity Study of Hybrid Gel Using MTT, BrdU and Neutral Red Assays}

The in vitro biocompatibility of the Alg- $\alpha$-TCP hybrid gel has been evaluated by measuring the cytotoxicity against specific cell organs (mitochondria, lysosome and DNA) using MTT, Neutral Red and BrdU assays.

Figure $8 \mathrm{~d}$ represents the cell viability results of the extracts of Teflon, latex and the hybrid gels. The extracts have been prepared after immersing the hybrid gels in media for 3 days and used for the study. Teflon and latex films has been used as positive and negative controls, respectively. The cytotoxicity of the hybrid gels against MC3T3 cells have been measured by comparing the optical densities of both Teflon and latex. The hybrid gels showed better cell viability than that of positive control (Teflon) in both MTT and Brd U assays (Figure 8d). The neutral red assay results showed lower $\%$ cell viability in hybrid gels than teflon, however, the viability is more than $90 \%$ and no significant difference is observed. Moreover, in all assays, the hybrid gels demonstrated much higher cell viability than negative control (latex). The results confirmed that the Alg- $\alpha$-TCP hybrid gel is biocompatible and non-toxic.

\subsection{In Vitro Protein (BSA) and Drugs (TCN and DMOG) Release Study from Alg- $\alpha$-TCP Hybrid Gel}

Figure 9 depicts the in vitro release study results of BSA, TCN and DMOG from different grades of Alg- $\alpha$-TCP (10:1, 2:1 and 1:10) hybrid gels. The release study has been performed at $\mathrm{pH} 4,7$ and 7.4 and $37^{\circ} \mathrm{C}$.

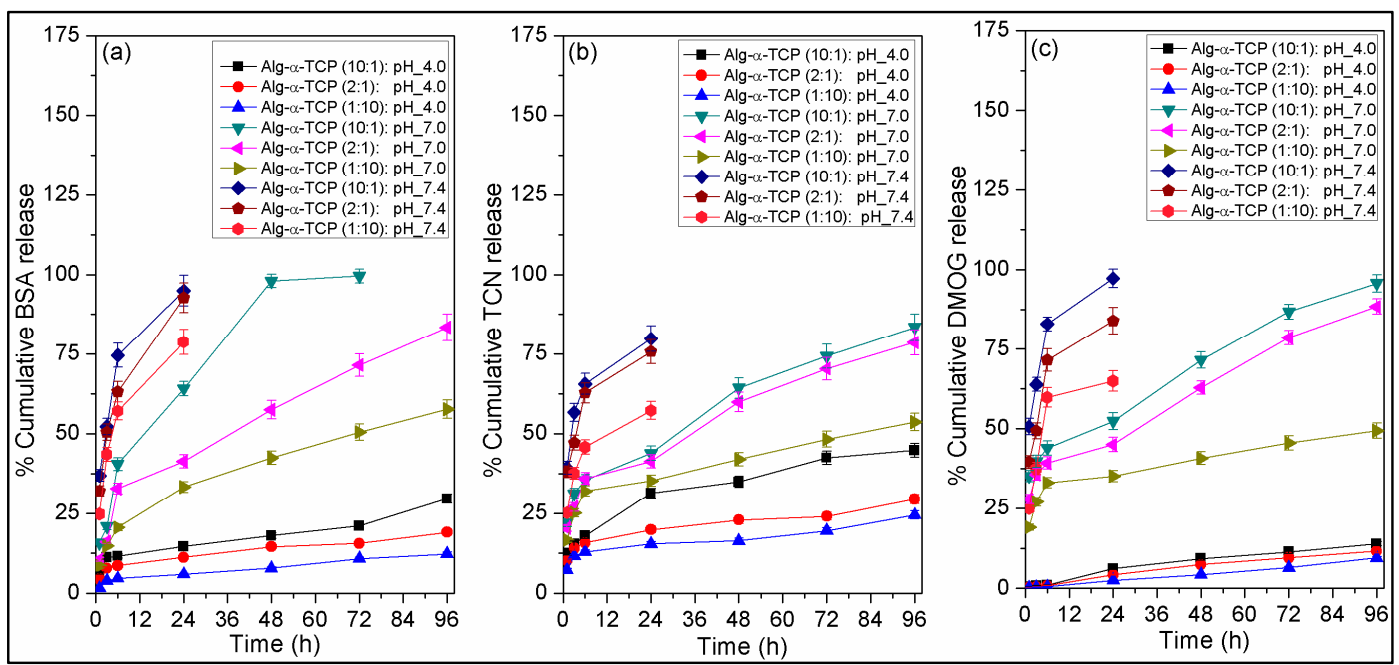

Figure 9. Plots of release of (a) BSA; (b) TCN and (c) DMOG from different grades of Alg- $\alpha$-TCP (10:1, 2:1 and 1:10) hybrid gels at $\mathrm{pH} 4.0,7.0$ and 7.4 and $37^{\circ} \mathrm{C}$.

From the Figure $9 \mathrm{a}-\mathrm{c}$, it is observed that at all media, the release rate of BSA, TCN and DMOG is lower for 1:10 hybrid gel, whereas, it is higher for 10:1 hybrid gel. The 10:1 hybrid gel released $\sim 30 \%$ BSA in 4 days at $\mathrm{pH} 4, \sim 100 \%$ BSA in 3 days at $\mathrm{pH} 7$ and $\sim 95 \%$ BSA in 1 day at pH 7.4 (Figure 9a). The same hybrid gel released $\sim 45 \%$ TCN in 4 days at $\mathrm{pH} 4, \sim 84 \% \mathrm{TCN}$ in 4 days at $\mathrm{pH} 7$ and $\sim 80 \% \mathrm{TCN}$ in 1 day at $\mathrm{pH} 7.4$ (Figure 9b). It also released $\sim 14 \%$ DMOG in 4 days at $\mathrm{pH} 4, \sim 96 \%$ DMOG in 4 days at $\mathrm{pH} 7$ and $\sim 97 \%$ DMOG in 1 day at $\mathrm{pH} 7.4$ (Figure 9c). This can be explained by the fact that for 10:1 hybrid gel, \% swelling and swelling rate are higher (Figure 6) because of the presence of lowest amount of $\alpha$-TCP, greater void space and larger pore sizes. For hydrogel system, rate of swelling is proportional to the drug release rate $[55,56]$. Consequently, diffusion rate of water molecules into the hybrid gel is higher for 10:1 hybrid gel which resulted higher \% protein/drug release. In case of 1:10 hybrid gel, due to the presence of higher amount of $\alpha$-TCP particles water molecules sense a barrier during the time of diffusion into the crosslinked gel network. As a result, 1:10 hybrid gel 
showed lowest amount of protein/drug release among three grades of gel. The release order followed is: 10:1 $>2: 1>1: 10$. From the Figure $9 \mathrm{a}-\mathrm{c}$, it has also been observed that release of BSA, TCN and DMOG significantly depends on the $\mathrm{pH}$ of the medium. Their release rates are higher at $\mathrm{pH} 7.4$ and lower at $\mathrm{pH}$ 4.0. As described in the swelling section that \% swelling and rate of swelling is highest for 10:1 system and lowest for 1:10 system. Thus, the release behaviors of BSA, TCN and DMOG followed the order at different buffers is: $\mathrm{pH} 7.4>\mathrm{pH} 7.0>\mathrm{pH} 4.0$ (Figure 9a-c). On the other hand, it is expected that the heat evolution during the transformation of $\alpha$-TCP to calcium-deficient hydroxyapatite (CDHAp), may also affect the release rate of drugs. It is assumed that the evolution of heat increased the diffusion of drugs from the hydrogel to media and thus release rate initially increased. Moreover, the extended periods of release of low molecular weight drugs (TCN and DMOG) indicates that drugs molecules formed stronger interaction with the newly developed small sized CDHAp particles and extended the release phenomena. In the literature, it is reported that $\sim 60-80 \%$ BSA was released from BSA-loaded alginate microcapsules after $24 \mathrm{~h}$ in acidic media [57]. There was a fast BSA release of $70 \%$ in $5 \mathrm{~h}$ from alginate microspheres at $\mathrm{pH} 7.4$ reported by Cetin et al. [58]. Cetin et al. described that the distraction of the calcium alginate matrix happened faster in a phosphate buffer above pH 5.5 owing to the chelating action of phosphate ions [58]. At pH 7.4, the affinity of calcium to phosphate was higher than that to alginate and subsequently, BSA was released from alginate microspheres through the constant erosion of the microspheres [58]. The erosion of the microspheres could cause the fast release of BSA from the microspheres [58]. Albumin release was dominated by a large initial burst and nearly $100 \% \mathrm{BSA}$ from the alginate $/ \mathrm{CaCl}_{2}$ microspheres in about $6 \mathrm{~h}$ [59]. Lin et al. reported $\sim 77-95 \%$ tetracycline release from alginate fibers at $6 \mathrm{~h}$ in PBS [60]. Srisuwan et al. depicted that because of the fast dissolution of the alginate film matrix at $\mathrm{pH} 7.4$, it released $\sim 95 \%$ of the loaded tetracycline within $3 \mathrm{~h}$ [61]. The above results showed that after modification with $\alpha-\mathrm{TCP}$, the Alg- $\alpha$-TCP gel released BSA, TCN and DMOG in a controlled way compared to reported native alginate matrix.

\subsection{Probable Interaction between Protein (BSA), Drugs (TCN and DMOG) and Hybrid Gel}

The release nature of protein/drugs from the cross-linked gel matrix depends on various factors like $\mathrm{pH}$ of the medium, temperature, size of the bioactive molecules, gel strength, swelling rate, $\%$ swelling as well as the interaction between bioactive molecules and matrix $[55,56]$. The molecular weights of BSA, DMOG and TCN are $\sim 66 \mathrm{kDa}, 175.1 \mathrm{Da}$ and $444.4 \mathrm{Da}$, respectively [49]. The comparatively slow release rate of DMOG and TCN suggests that they are strongly bound (stronger interaction) with the hydrogel compared to BSA. The possible interaction between BSA/TCN/DMOG and the hybrid gel has been identified by FTIR analysis. It is apparent that physical interaction, mainly H-bonding is responsible to bind the drugs into the Alg- $\alpha$-TCP hydrogel. Briefly, from the Figure 10a(1-3), it is apparent that the peaks in the FTIR spectrum of BSA at 3286, 2929, 1649, 1530 and $1452 \mathrm{~cm}^{-1}$ are because of the $\mathrm{N}-\mathrm{H} / \mathrm{O}-\mathrm{H}$ stretching, $\mathrm{C}-\mathrm{H}$ stretching, stretching vibrations of amide I, amide-II of peptide unit and stretching vibration of $-\mathrm{COO}^{-}$group of BSA, respectively. From the FTIR spectra of BSA-incorporated hybrid gels it has been noticed that all the characteristics peaks i.e., for $\mathrm{N}-\mathrm{H}$ stretching, amide-I, amide-II are present in the spectra. However, the peaks for $\mathrm{N}-\mathrm{H}$ bond at $3286 \mathrm{~cm}^{-1}$ broaden and the peaks value for amide-I shift from 1649 to $1637 \mathrm{~cm}^{-1}$ which indicate there is a physical interaction between BSA and hybrid gel. In the FTIR spectrum of TCN (Figure 10b(1-3)), the peaks at $3265,2981,1640,1579,1511,1450 \mathrm{~cm}^{-1}$ are due to $\mathrm{N}-\mathrm{H} / \mathrm{O}-\mathrm{H}$ stretching (intramolecular $\mathrm{H}$-bonded), $\mathrm{C}-\mathrm{H}$ stretching, amide-I, stretching vibrations of $-\mathrm{C}=\mathrm{O}$ of keto-enol functional ring, amide-II stretching and $\mathrm{C}=\mathrm{C}$ group, respectively. However, the broad peak at $3265 \mathrm{~cm}^{-1}$ merged with the peak of $-\mathrm{OH}$ group of Alg and appeared at $3293 \mathrm{~cm}^{-1}$ in the FTIR spectra of TCN-incorporated hybrid gel. Besides, the shifting of peaks of amide-I and amide-II (1600 and $\left.1426 \mathrm{~cm}^{-1}\right)$ indicates physical interaction (H-bonding) and good compatibility between TCN and hybrid gel. From the FTIR spectrum of DMOG (Figure 10c(1-3)), it is apparent that the peaks at 3379, 2954, 1748, 1687 and $1535 \mathrm{~cm}^{-1}$ are responsible for the $\mathrm{N}-\mathrm{H}$ stretching, $-\mathrm{C}=\mathrm{O}$ of ester group, amide-I and amide-II stretching 
vibrations, respectively. While in the FTIR spectra of DMOG-incorporated hybrid gels, the broadness and merge of $\mathrm{N}-\mathrm{H}$ peak $\left(3294 \mathrm{~cm}^{-1}\right)$ and shifting of $-\mathrm{C}=\mathrm{O}$ of ester group $\left(1737 \mathrm{~cm}^{-1}\right)$, amide-I and amide-II stretching vibrations $\left(1605,1591,1520,1521 \mathrm{~cm}^{-1}\right)$ imply good compatibility between DMOG and hybrid gel, followed by physical interaction.
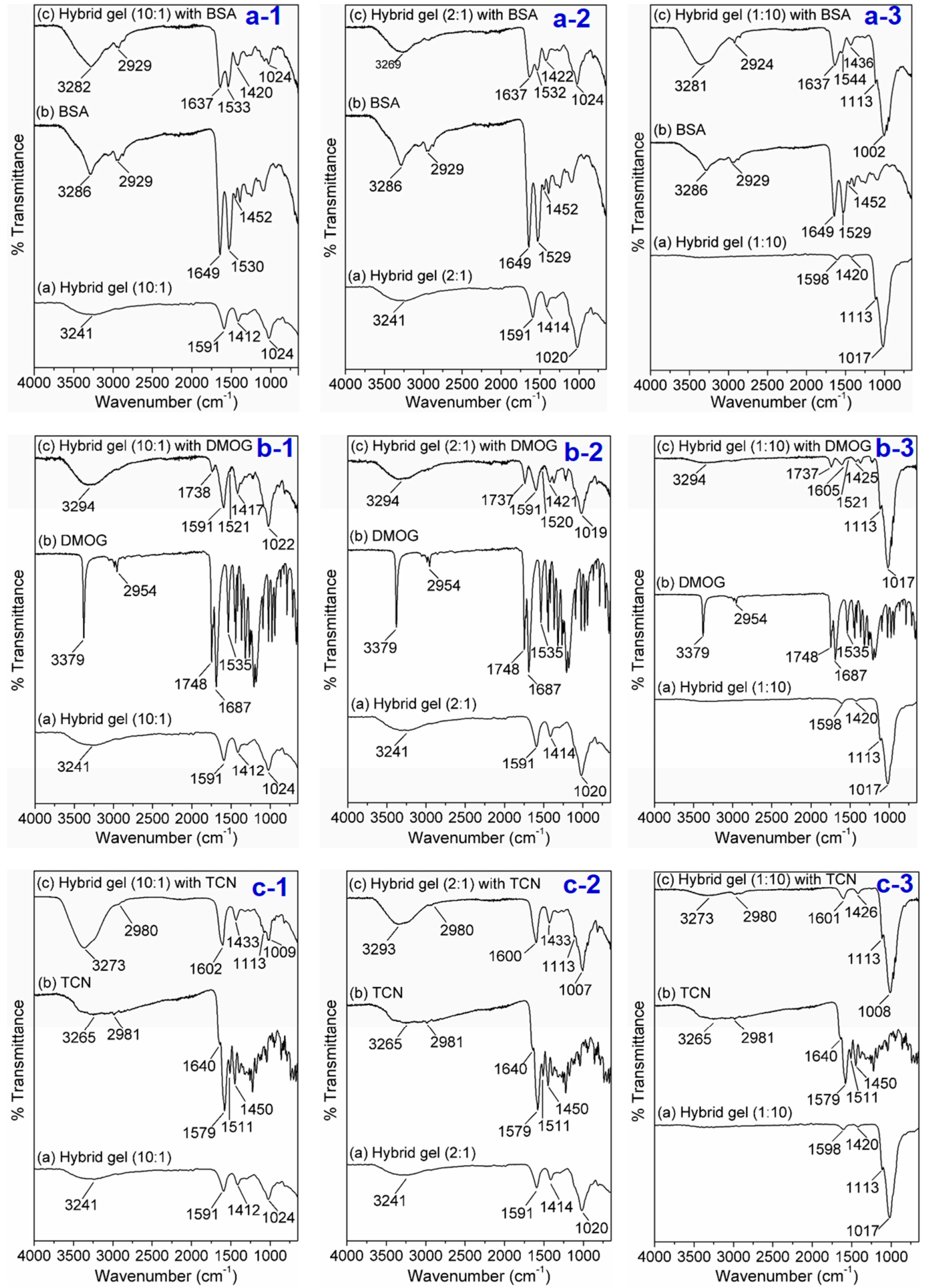

Figure 10. FTIR spectra for the detection of probable interaction between BSA (a-1-3), DMOG (b-1-3), TCN (c-1-3) and Alg- $\alpha$-TCP (10:1, 2:1 and 1:10) hybrid gels. 


\section{Conclusions}

After synthesis of Alg- $\alpha$-TCP hydrogel by ionic crosslinking, diverse gel responses studies such as gelatin time, morphological changes, swelling, encapsulated cell viability as well as release behavior of bioactive molecules have been carried out. While the physicochemical analyses of the hybrid gel have been performed to verify its structure and components and to understand the mechanisms of swelling characteristics, in vitro drug/protein release behaviors and in vitro cellular responses under different $\mathrm{pH}$. The ATR-FTIR analysis suggested ionic crosslinking happened in presence of $\mathrm{Ca}^{2+}$ ions. The SEM analysis showed that the $\alpha$-TCP are distributed on the surface of the hybrid gel as well as are embedded into the porous crosslinked gel network. The stimuli-responsiveness of the hybrid gel has been ascertained from the $\mathrm{pH}$-sensitive swelling behaviors. The amount of filler ( $\alpha$-TCP particles) greatly affected the swelling characteristics of the hybrid gel, where, higher $\% \alpha$-TCP induced lower $\%$ swelling. In vitro MC3T3 cell proliferation and viability inside the hybrid gel confirmed that the synthesized hybrid gel is biocompatible. The $\mathrm{pH}$ variation cell study suggested that cell proliferation is higher at $\mathrm{pH} 7.4$ rather than $\mathrm{pH}$ 7. The in vitro cytotoxicity analyses using MTT, BrdU and neutral red assays ascertained that the Alg- $\alpha$-TCP hybrid gel in non-toxic for MC3T3 cells. The hybrid gel released protein (BSA) and drugs (TCN, DMOG) in higher rate at $\mathrm{pH} 7.4$ than those of $\mathrm{pH} 7.0$ and $\mathrm{pH} 4.0$. FTIR spectra ascertained that BSA, DMOG and TCN molecules reside into the Alg- $\alpha$-TCP matrix by physical interaction especially through H-bonding. The drugs/protein release results showed that the Alg- $\alpha$-TCP hybrid gel released BSA, DMOG and TCN in controlled way. The experimental results signified that the biocompatible Alg- $\alpha$-TCP hybrid gel could potentially be employed as scaffold in bone tissue engineering, along with as future ink for 3D bioprinting technology.

Acknowledgments: Authors are thankful to Hoon Choi and M. Mehtab for cooperation during the synthesis of $\alpha$-TCP and drug release study, Yunjung Yang for cell culture. This work is supported by the National Research Foundation of Korea (NRF) Grants (2014K2A2A7060928 and 2015R1A2A1A10054592) and National Natural Science Foundation of China (NSFC No. 81461148032).

Author Contributions: Dipankar Das worked most of experiments and wrote down the paper. Sumi Bang did the cytotoxicity study. Insup Noh and Shengmin Zhang supervised the research. All authors discussed the results and commented on the manuscript.

Conflicts of Interest: The authors declare no conflict of interest.

\section{References}

1. Das, D.; Ghosh, P.; Dhara, S.; Panda, A.B.; Pal, S. Dextrin and poly(acrylic acid)-based biodegradable, non-Cytotoxic, chemically cross-linked hydrogel for sustained release of ornidazole and ciprofloxacin. ACS Appl. Mater. Interfaces 2015, 7, 4791-4803. [CrossRef] [PubMed]

2. Bang, S.; Das, D.; Yu, J.; Noh, I. Evaluation of MC3T3 cells proliferation and drug release study from sodium hyaluronate-1,4-butanediol diglycidyl ether patterned gel. Nanomaterials 2017, 7, 328. [CrossRef] [PubMed]

3. Giordano, C.; Albani, D.; Gloria, A.; Tunesi, M.; Batelli, S.; Russo, T.; Forloni, G.; Ambrosio, L.; Cigada, A. Multidisciplinary perspectives for Alzheimer's and Parkinson's diseases: Hydrogels for protein delivery and cell-based drug delivery as therapeutic strategies. Int. J. Artif. Organs 2009, 32, 836-850. [PubMed]

4. Patel, N.R.; Whitehead, A.K.; Newman, J.J.; Caldorera-Moore, M.E. Poly(ethylene glycol) hydrogels with tailorable surface and mechanical properties for tissue engineering applications. ACS Biomater. Sci. Eng. 2017, 3, 1494-1498. [CrossRef]

5. Chuah, Y.J.; Peck, Y.; Lau, J.E.J.; Hee, H.T.; Wang, D.A. Hydrogel based cartilaginous tissue regeneration: Recent insights and technologies. Biomater. Sci. 2017, 5, 613-631. [CrossRef] [PubMed]

6. Luca, A.; Butnaru, M.; Maier, S.S.; Knieling, L.; Bredetean, O.; Verestiuc, L.; Dimitriu, D.C.; Popa, M. Atelocollagen-based hydrogels crosslinked with oxidized polysaccharides as cell encapsulation matrix for engineered bioactive stromal tissue. Tissue Eng. Regen. Med. 2017, 14, 539-556. [CrossRef]

7. Ahadian, S.; Sadeghian, R.B.; Salehi, S.; Ostrovidov, S.; Bae, H.; Ramalingam, M.; Khademhosseini, A. Bioconjugated hydrogels for tissue engineering and regenerative medicine. Bioconjugate Chem. 2015, 26, 1984-2001. [CrossRef] [PubMed] 
8. Giordano, C.; Albani, D.; Gloria, A.; Tunesi, M.; Rodilossi, S.; Russo, T.; Forloni, G.; Ambrosio, L.; Cigada, A. Nanocomposites for neurodegenerative diseases: Hydrogel-nanoparticle combinations for a challenging drug delivery. Int. J. Artif. Organs 2011, 34, 1115-1127. [CrossRef] [PubMed]

9. Zhao, F.; Wu, D.; Yao, D.; Guo, R.; Wang, W.; Dong, A.; Kong, D.; Zhang, J. An injectable particle-hydrogel hybrid system for glucose-regulatory insulin delivery. Acta Biomater. 2017, 64, 334-345. [CrossRef] [PubMed]

10. Zhang, K.; Lin, S.; Feng, Q.; Dong, C.; Yang, Y.; Li, G.; Bian, L. Nanocomposite hydrogels stabilized by self-assembled multivalent bisphosphonate-magnesium nanoparticles mediate sustained release of magnesium ion and promote in-situ bone regeneration. Acta Biomater. 2017, 64, 389-400. [CrossRef] [PubMed]

11. Bjørnøy, S.H.; Bassett, D.C.; Ucar, S.; Strand, B.L.; Andreassen, J.P.; Sikorski, P. A correlative spatiotemporal microscale study of calcium phosphate formation and transformation within an alginate hydrogel matrix. Acta Biomater. 2016, 44, 254-266. [CrossRef] [PubMed]

12. Gaharwar, A.K.; Peppas, N.A.; Khademhosseini, A. Nanocomposite hydrogels for biomedical applications. Biotechnol. Bioeng. 2014, 111, 441-453. [CrossRef] [PubMed]

13. Egorov, A.A.; Fedotov, A.Y.; Mironov, A.V.; Komlev, V.S.; Popov, V.K.; Zobkov, Y.V. 3D printing of mineral-polymer bone substitutes based on sodium alginate and calcium phosphate. Beilstein J. Nanotechnol. 2016, 7, 1794-1799. [CrossRef] [PubMed]

14. Huang, B.; Liu, M.; Long, Z.; Shen, Y.; Zhou, C. Effects of halloysite nanotubes on physical properties and cytocompatibility of alginate composite hydrogels. Mater. Sci. Eng. C 2017, 70, 303-310. [CrossRef] [PubMed]

15. Yang, S.; Leong, K.F.; Du, Z.; Chua, C.K. The design of scaffolds for use in tissue engineering. Part I. traditional factors. Tissue Eng. 2001, 7, 679-689. [CrossRef] [PubMed]

16. Huh, J.T.; Lee, J.U.; Kim, W.J.; Yeo, M.; Kim, G.H. Preparation and characterization of gelatin/ $\alpha-\mathrm{TCP} / \mathrm{SF}$ biocomposite scaffold for bone tissue regeneration. Int. J. Biol. Macromol. 2017. [CrossRef] [PubMed]

17. Woodard, J.R.; Hilldore, A.J.; Lan, S.K.; Park, C.; Morgan, A.W.; Eurell, J.A.C.; Clark, S.G.; Wheeler, M.B.; Jamison, R.D.; Johnson, A.J.W. The mechanical properties and osteoconductivity of hydroxyapatite bone scaffolds with multi-scale porosity. Biomaterials 2007, 28, 45-54. [CrossRef] [PubMed]

18. Bose, S.; Roy, M.; Bandyopadhyay, A. Recent advances in bone tissue engineering scaffolds. Trends Biotechnol. 2012, 30, 546-554. [CrossRef] [PubMed]

19. Bignon, A.; Chouteau, J.; Chevalier, J.; Fantozzi, G.; Carret, J.P.; Chavassieux, P.; Boivin, G.; Melin, M.; Hartmann, D. Effect of micro-and macroporosity of bone substitutes on their mechanical properties and cellular response. J. Mater. Sci. Mater. Med. 2003, 14, 1089-1097. [CrossRef] [PubMed]

20. Liu, X.; Ma, P.X. Polymeric scaffolds for bone tissue engineering. Ann. Biomed. Eng. 2004, 32, 477-486. [CrossRef] [PubMed]

21. Liu, X.; Holzwarth, J.M.; Ma, P.X. Functionalized synthetic biodegradable polymer scaffolds for tissue engineering. Macromol. Biosci. 2012, 12, 911-919. [CrossRef] [PubMed]

22. Tsaryk, R.; Gloria, A.; Russo, T.; Anspach, L.; De Santis, R.; Ghanaati, S.; Unger, R.E.; Ambrosio, L.; Kirkpatrick, C.J. Collagen-low molecular weight hyaluronic acid semi-interpenetrating network loaded with gelatin microspheres for cell and growth factor delivery for nucleus pulposus regeneration. Acta Biomater. 2015, 20, 10-21. [CrossRef] [PubMed]

23. Dabiri, S.M.H.; Lagazzo, A.; Barberis, F.; Farokhi, M.; Finochio, E.; Pastorino, L. Characterization of alginate-brushite in-situ hydrogel composites. Mater. Sci. Eng. C 2016, 67, 502-510. [CrossRef] [PubMed]

24. Graulus, G.J.; Mignon, A.; Vlierberghe, S.V.; Declercq, H.; Fehér, K.; Cornelissen, M.; Martins, J.C.; Dubruel, P. Cross-linkable alginate-graft-gelatin copolymers for tissue engineering applications. Eur. Polym. J. 2015, 72, 494-506. [CrossRef]

25. Pawar, S.N.; Edgar, K.J. Alginate derivatization: A review of chemistry, properties and applications. Biomaterials 2012, 33, 3279-3305. [CrossRef] [PubMed]

26. Son, K.D.; Kim, Y.J. Anticancer activity of drug-loaded calcium phosphate nanocomposites against human osteosarcoma. Biomater. Res. 2017, 21, 13. [CrossRef] [PubMed]

27. Castilho, M.; Rodrigues, J.; Pires, I.; Gouveia, B.; Pereira, M.; Moseke, C.; Groll, J.; Ewald, A.; Vorndran, E. Fabrication of individual alginate-TCP scaffolds for bone tissue engineering by means of powder printing. Biofabrication 2015, 7, 015004. [CrossRef] [PubMed] 
28. Pype, R.J.; Binnemans, K.; Mullens, S. Shaping of alginate-silica hybrid materials into microspheres through vibrating-nozzle technology and their use for the recovery of neodymium from aqueous solutions. Ind. Eng. Chem. Res. 2015, 54, 12836-12846.

29. Ionita, M.; Pandele, M.A.; Iovu, H. Sodium alginate/graphene oxide composite films with enhanced thermal and mechanical properties. Carbohydr. Polym. 2013, 94, 339-344. [CrossRef] [PubMed]

30. Mahapatra, C.; Zhen, G.; Kim, J.W. Alginate-hyaluronic acid-collagen composite hydrogel favorable for the culture of chondrocytes and their phenotype maintenance. Tissue Eng. Regen. Med. 2016, 13, 538-546. [CrossRef]

31. Lee, G.S.; Shin, U.S.; Park, J.H.; Kim, H.W.; Won, J.E. Alginate combined calcium phosphate cements: Mechanical properties and in vitro rat bone marrow stromal cell responses. J. Mater. Sci. Mater. Med. 2011, 22, 1257-1268. [CrossRef] [PubMed]

32. Perez, R.A.; Kim, H.W. Core-shell designed scaffolds of alginate/alpha-tricalcium phosphate for the loading and delivery of biological proteins. J. Biomed. Mater. Res. Part A 2013, 101A, 1103-1112. [CrossRef] [PubMed]

33. Perez, R.A.; Kim, J.H.; Buitrago, J.O.; Wall, I.B.; Kim, H.W. Novel therapeutic core-shell hydrogel scaffolds with sequential delivery of cobalt and bone morphogenetic protein-2 for synergistic bone regeneration. Acta Biomater. 2015, 23, 295-308. [CrossRef] [PubMed]

34. Sheikh, Z.; Hamdan, N.; Oleda, U.; Grynpas, M.; Ganss, B.; Glogauer, M. Natural graft tissues and synthetic biomaterials for periodontal and alveolar bone reconstructive applications: A review. Biomater. Res. 2017, 21, 9. [CrossRef] [PubMed]

35. Seidenstuecker, M.; Ruehe, J.; Suedkamp, N.P.; Serr, A.; Wittmer, A.; Bohner, M.; Bernstein, A.; Mayr, H.O. Composite material consisting of microporous $\beta$-TCP ceramic and alginate for delayed release of antibiotics. Acta Biomater. 2017, 51, 433-446. [CrossRef] [PubMed]

36. Wang, K.; Nune, K.C.; Misra, R.D.K. The functional response of alginate-gelatin-nanocrystalline cellulose injectable hydrogels toward delivery of cells and bioactive molecules. Acta Biomater. 2016, 36, 143-151. [CrossRef] [PubMed]

37. Raja, N.; Yun, H.S. A simultaneous 3D printing process for the fabrication of bioceramics and cell-laden hydrogel core/shell scaffolds with potential application in bone tissue regeneration. J. Mater. Chem. B 2016, 4, 4707-4716. [CrossRef]

38. Akkouch, A.; Zhang, Z.; Rouabhia, M. A novel collagen/hydroxyapatite/poly (lactide-co- $\varepsilon$-caprolactone) biodegradable and bioactive 3D porous scaffold for bone regeneration. J. Biomed. Mater. Res. Part A 2011, 96, 693-704. [CrossRef] [PubMed]

39. Asaoka, T.; Ohtake, S.; Furukawa, K.S.; Tamura, A.; Ushida, T. Development of bioactive porous $\alpha$-TCP/Hap beads for bone tissue engineering. J. Biomed. Mater. Res. Part A 2013, 101A, 3295-3300. [CrossRef] [PubMed]

40. Hahn, B.D.; Park, D.S.; Choi, J.J.; Ryu, J.; Yoon, W.H.; Choi, J.H.; Kim, J.W.; Ahn, C.W.; Kim, H.E.; Yoon, B.H. Osteoconductive hydroxyapatite coated PEEK for spinal fusion surgery. Appl. Surf. Sci. 2013, 283, 6-11. [CrossRef]

41. Sulaiman, S.B.; Keong, T.K.; Cheng, C.H.; Saim, A.B.; Hj Idrus, R.B. Tricalcium phosphate/hydroxyapatite (TCP-HA) bone scaffold as potential candidate for the formation of tissue engineered bone. Indian J. Med. Res. 2013, 137, 1093-1101. [PubMed]

42. Angela, N.M.; Aminuddin, B.S.; Tan, K.K.; Tan, G.H.; Isa, M.R.; Fauziah, O. Comparison of bioengineered human bone construct from four sources of osteogenic cells. J. Orthop. Sci. 2005, 10, 192-199.

43. Naskar, A.; Khan, H.; Bera, S.; Jana, S. Soft chemical synthesis, characterization and interaction of ZnO graphene nanocomposite with bovine serum albumin protein. J. Mol. Liq. 2017, 237, 113-119. [CrossRef]

44. Chakraborti, S.; Joshi, P.; Chakravarty, D.; Shanker, V.; Ansari, Z.A.; Singh, S.P.; Chakrabarti, P. Interaction of polyethyleneimine-functionalized $\mathrm{ZnO}$ nanoparticles with bovine serum albumin. Langmuir 2012, 28, 11142-11152. [CrossRef] [PubMed]

45. Kathiravan, A.; Renganathan, R.; Anandan, S. Interaction of colloidal $\mathrm{AgTiO}_{2}$ nanoparticles with bovine serum albumin. Polyhedron 2009, 28, 157-161. [CrossRef]

46. Yu, H.; Nguyen, M.H.; Cheow, W.S.; Hadinoto, K. A new bioavailability enhancement strategy of curcumin via self-assembly nano-complexation of curcumin and bovine serum albumin. Mater. Sci. Eng. C 2017, 75, 25-33. [CrossRef] [PubMed] 
47. Ding, H.; Chen, S.; Song, W.Q.; Gao, Y.S.; Guan, J.J.; Wang, Y.; Sun, Y.; Zhang, C.Q. Dimethyloxaloylglycine improves angiogenic activity of bone marrow stromal cells in the tissue-engineered bone. Int. J. Biol. Sci. 2014, 10, 746-756. [CrossRef] [PubMed]

48. Zhang, J.; Guan, J.; Qi, X.; Ding, H.; Yuan, H.; Xie, Z.; Li, X.; Zhang, C.; Huang, Y.; Chen, C. Dimethyloxaloylglycine promotes the angiogenic activity of mesenchymal stem cells derived from iPSCs via activation of the PI3K/Akt pathway for bone regeneration. Int. J. Biol. Sci. 2016, 12, 639-652. [CrossRef] [PubMed]

49. Das, D.; Zhang, S.; Noh, I. Synthesis and characterizations of alginate- $\alpha$-tricalcium phosphate microparticle hybrid film with flexibility and high mechanical property as biomaterials. Biomed. Mater. 2017. [CrossRef] [PubMed]

50. Carrodeguas, R.G.; Aza, S.D. $\alpha$-Tricalcium phosphate: Synthesis, properties and biomedical applications. Acta Biomater. 2011, 7, 3536. [CrossRef] [PubMed]

51. Gallinetti, S.; Canal, C.; Ginebra, M.P.; Ferreira, J. Development and characterization of biphasic hydroxyapatite/ $\beta$-TCP cements. J. Am. Ceram. Soc. 2014, 97, 1065-1073. [CrossRef] [PubMed]

52. Grant, G.T.; Morris, E.R.; Rees, D.A.; Smith, P.J.C.; Thom, D. Biological interactions between polysaccharides and divalent cations: The egg-box model. FEBS Lett. 1973, 32, 195-198. [CrossRef]

53. TenHuisen, K.S.; Brown, P.W. Formation of calcium-deficient hydroxyapatite from alpha-tricalcium phosphate. Biomaterials 1998, 19, 2209-2217. [CrossRef]

54. Touny, A.H.; Laurencin, C.; Nair, L.; Allcock, H.; Brown, P.W. Formation of composites comprised of calcium deficient HAp and cross-linked gelatin. J. Mater. Sci. Mater. Med. 2008, 19, 3193-3201. [CrossRef] [PubMed]

55. Patra, P.; Rameshbabu, A.P.; Das, D.; Dhara, S.; Panda, A.B.; Pal, S. Stimuli-responsive, biocompatible hydrogel derived from glycogen and poly( $N$-isopropyl acrylamide) for colon targeted delivery of ornidazole and 5-amino salicylic acid. Polym. Chem. 2016, 7, 5426-5435. [CrossRef]

56. Das, D.; Ghosh, P.; Ghosh, A.; Haldar, C.; Dhara, S.; Panda, A.B.; Pal, S. Stimulus-responsive, biodegradable, biocompatible, covalently cross-linked hydrogel based on dextrin and poly( $N$-isopropyl acrylamide) for in vitro/in vivo controlled drug release. ACS Appl. Mater. Interfaces 2015, 7, 14338-14351. [CrossRef] [PubMed]

57. Benchabane, S.; Subirade, M.; Vandenberg, G.W. Production of BSA-loaded alginate microcapsules: Influence of spray dryer parameters on the microcapsule characteristics and BSA release. J. Microencapsul. 2007, 24, 647-658. [CrossRef] [PubMed]

58. Cetin, M.; Vural, I.; Capan, Y.; Hincal, A.A. Preparation and characterization of BSA-loaded alginate microspheres. FABAD J. Pharm. Sci. 2007, 32, 103-107.

59. Liu, L.S.; Liu, S.Q.; Ng, S.Y.; Froix, M.; Ohno, T.; Heller, J. Controlled release of interleukin-2 for tumor immunotherapy using alginate/chitosan porous microspheres. J. Control. Release 1997, 43, 65-74. [CrossRef]

60. Lin, H.Y.; Wang, H.W. The influence of operating parameters on the drug release and antibacterial performances of alginate fibrous dressings prepared by wet spinning. Biomatter 2012, 2, 321-328. [CrossRef] [PubMed]

61. Srisuwan, Y.; Baimark, Y. Preparation of biodegradable silk fibroin/alginate blend films for controlled release of antimicrobial drugs. Adv. Mater. Sci. Eng. 2013, 2013, 412458. [CrossRef]

(C) 2017 by the authors. Licensee MDPI, Basel, Switzerland. This article is an open access article distributed under the terms and conditions of the Creative Commons Attribution (CC BY) license (http:/ / creativecommons.org/licenses/by/4.0/). 